Article

\title{
Oxymatrine Attenuates Tumor Growth and Deactivates STAT5 Signaling in a Lung Cancer Xenograft Model
}

\author{
Young Yun Jung ${ }^{1}$, Muthu K. Shanmugam ${ }^{2}$, Acharan S. Narula ${ }^{3}$, Chulwon Kim ${ }^{1,4}$, \\ Jong Hyun Lee ${ }^{1,4}$, Ojas A. Namjoshi ${ }^{5}$, Bruce E. Blough ${ }^{5}$, Gautam Sethi ${ }^{2, *}$ and \\ Kwang Seok Ahn 1,4,6,*(D)
}

1 Department of Science in Korean Medicine, Kyung Hee University, 24 Kyungheedae-ro, Dongdaemun-gu, Seoul 02447, Korea; ve449@naver.com (Y.Y.J.); sunny10526@nate.com (C.K.); mirue88@nate.com (J.H.L.)

2 Department of Pharmacology, Yong Loo Lin School of Medicine, National University of Singapore, Singapore 117600, Singapore; phcsmk@nus.edu.sg

3 Naula Research, Chapel Hill, NC 27516, USA; anarula1@nc.rr.com

4 Comorbidity Research Institute, College of Korean Medicine, Kyung Hee University, 24 Kyungheedae-ro, Dongdaemun-gu, Seoul 02447, Korea

5 Center for Drug Discovery, RTI International, Research Triangle Park, Durham, NC 27616, USA; onamjoshi@rti.org (O.A.N.); beb@rti.org (B.E.B.)

6 Department of Korean Pathology, College of Korean Medicine, Kyung Hee University, 24 Kyungheedae-ro, Dongdaemun-gu, Seoul 02447, Korea

* Correspondence: phcgs@nus.edu.sg (G.S.); ksahn@khu.ac.kr (K.S.A.); Tel.: +65-6516-3267 (G.S.); +82-2-961-2316 (K.S.A.)

Received: 29 November 2018; Accepted: 28 December 2018; Published: 7 January 2019

\begin{abstract}
Oxymatrine (OMT) is a major alkaloid found in radix Sophorae flavescentis extract and has been reported to exhibit various pharmacological activities. We elucidated the detailed molecular mechanism(s) underlying the therapeutic actions of OMT in non-small cell lung cancer (NSCLC) cells and a xenograft mouse model. Because the STAT5 signaling cascade has a significant role in regulating cell proliferation and survival in tumor cells, we hypothesized that OMT may disrupt this signaling cascade to exert its anticancer effects. We found that OMT can inhibit the constitutive activation of STAT5 by suppressing the activation of JAK1/2 and c-Src, nuclear localization, as well as STAT5 binding to DNA in A549 cells and abrogated IL-6-induced STAT5 phosphorylation in H1299 cells. We also report that a sub-optimal concentration of OMT when used in combination with a low dose of paclitaxel produced significant anti-cancer effects by inhibiting cell proliferation and causing substantial apoptosis. In a preclinical lung cancer mouse model, OMT when used in combination with paclitaxel produced a significant reduction in tumor volume. These results suggest that OMT in combination with paclitaxel can cause an attenuation of lung cancer growth both in vitro and in vivo.
\end{abstract}

Keywords: oxymatrine; STAT5; apoptosis; NSCLC

\section{Introduction}

Non-small cell lung cancer (NSCLC) is the most common and lethal cancer worldwide, affecting both men and women [1,2]. One of the most frequently encountered causes for NSCLC has been found to be tobacco smoking [3]. NSCLC is more common in women and in East Asia is often associated with environmental factors such as exposure to occupational carcinogens, second-hand smoke, pollution, and genetic susceptibility [2,4-9]. Several common variant allele frequencies of alterations have been also found in NSCLC patients such as somatic mutations, homozygous deletions, focal amplifications, 
and significant up- or downregulation of gene expression in Kirsten rat sarcoma (KRAS) and epidermal growth factor receptor (EGFR) [2]. Current treatments for advanced lung cancer include chemotherapy, targeted therapies, and surgical removal of tumor followed by radiation therapy [10]. However, the existing treatment modalities exhibit serious side effects in patients. Therefore, the identification and development of novel and efficient drugs from alternative sources such as Mother Nature are urgently required [11-21].

Signal transducer and activator of transcription 5 (STAT5) is a pro-survival transcription factor that is known to regulate several critical cellular functions and in the maintenance of cellular homeostasis and is often found to be deregulated in cancers [22-24]. Among the STAT family of proteins, STAT5 has been closely implicated in the development of a variety of cancers including hematological malignancies and solid tumors $[25,26]$. Constitutive phosphorylation of tyrosine residue (Tyr694/Tyr699) and transcriptional activation of STAT5 have been observed in diverse malignancies [27-30]. Phosphorylation of tyrosine residue occurs through the activation of intracellular kinases such as JAK1/2 and c-Src [31-33]. Moreover, potential mechanistic crosstalk of STAT5 with the PI3K/AKT pathway has also been observed during normal mammary gland development and during tumorigenesis [34-36]. In A549 lung cancer cells, epidermal-growth-factor-induced COX-2 expression has been implicated in tumor progression through the activation of the STAT5 signaling pathway [37]. It has also been found that the silencing of miR10a reversed resistance lung cancer resistance to cisplatin by modulating the TGF $\beta$ /Smad2/STAT3/STAT5 pathway [38]. Several studies have also reported that natural and/or synthetic pharmacological agents that can modulate STAT5 signaling pathway may have tremendous potential in the therapy of cancer [39-44]. STAT5 can play a pivotal role in the development of Tregs and may also be associated with suppression of antitumor immunity and thus can serve as a potential therapeutic target [31,45].

Traditional Chinese medicine (TCM) originated in China and it has long been practiced in several East Asian countries for over thousands of years [46]. In view of its important contribution to Chinese medical practices, the Chinese state food and drug administration has approved TCM for the clinical treatment of solid tumors [46,47]. TCM has been used as an adjuvant therapy in patients undergoing standard chemotherapy and radiotherapy and has been shown to reduce the adverse effects associated with cancer therapy [48]. Furthermore, clinical trials in cancer patients with TCM formulations were found to reduce tumor burden, strengthen immune function, and improve overall quality of life [48,49]. Matrine and oxymatrine (OMT) are two major alkaloids found in radix Sophorae flavescentis belonging to the family Leguminosae that can exhibit diverse pharmacological activities such as anti-inflammatory, anti-viral, anti-allergic, anti-cancer, and cardiovascular protective effects [46,50].

Interestingly, OMT was found to abrogate breast cancer cell proliferation and downregulate the Wnt/ $\beta$-catenin signaling pathway [51]. OMT also inhibited the growth of PANC-1 pancreatic cancer cells and induced apoptosis by downregulating anti-apoptotic protein such as Bcl-2 and the induction of caspase 3 [52]. OMT either alone or in combination with angiogenesis inhibitor NM3 synergistically inhibited the growth of human gastric cancer cells in vitro and abrogated the growth of SGC-7901 cells in vivo [53]. In another study, OMT was noted to attenuate the growth, induce apoptosis, and inhibit the expression of Bcl-2 protein with a concomitant increase in the expression of the $p 53$ gene in human hepatoma SMMC-7721 cells in vitro [54]. In another study, using human hepatocellular carcinoma cells HepG2 and SMMC-7721, OMT reduced proliferation in a dose-dependent manner and induced apoptosis. Moreover, in combination with 5-fluorouracil, OMT can produce a synergistic anti-tumor effect both in vitro and in vivo [55]. Several recent studies have demonstrated the anticancer effects of OMT in diverse cancer cell lines such as prostate cancer [56], ovarian cancer [57], gastric cancer [58], colorectal cancer [59-61], breast cancer [62,63], bladder cancer [64], hepatocellular carcinoma [55], esophageal carcinoma [65], osteosarcoma [66,67], cervical cancer [68,69], gallbladder carcinoma [70], laryngeal carcinoma [71], hemangioma [72], lung cancer [73-76], synovial sarcoma [77], glioblastoma [78,79], and nasopharyngeal carcinoma [80]. The molecular mechanism(s) of action of 
OMT was found to be mediated by inducing cell cycle arrest and apoptosis and by causing an inhibition of angiogenesis and metastasis [57,64,81,82].

In addition, matrine has also been shown to inhibit the growth of several organ-specific cancers such as breast cancer, gastric cancer, gallbladder cancer, osteosarcoma, and hepatocellular carcinoma by modulating pro-survival cell signaling pathways and the induction of apoptosis [47]. In breast cancer cells, matrine suppressed the phosphorylation of NF- $\mathrm{kB}$ and its subsequent nuclear translocation in MCF-7 and BT549, MDA-MB-231 triple negative breast cancer cells [83]. In another study, matrine was found to induce cell cycle arrest and apoptosis by suppressing the expression of micro-RNA21, upregulating the expression of tumor suppressor protein PTEN and thereby inhibiting the PI3K/AKT signaling pathway [84]. In gastric cancer cells, matrine induced dose- and time-dependent apoptosis that was found to be associated with an increase in caspase-3 activity [85]. Similarly, in MKN45 gastric cancer cells, matrine inhibited proliferation, upregulated caspase-3 and -7 , and induced apoptosis [86]. Dysregulation of microRNAs, a class of small, non-coding, regulatory RNA molecules involved in gene expression, has been reported to be strongly associated with cancer initiation and progression. Interestingly, matrine can alter microRNA expression profiles in SGC-7901 human gastric cancer cells. Matrine upregulated 128 miRNAs substantially exhibiting $>2$-fold expression changes in treated cells compared to the untreated control cells [87].

In this study, we primarily focused to investigate the potential anticancer effects of OMT in NSCLC cell lines and a xenograft mouse model. We found that the anti-neoplastic effects of OMT may be primarily mediated through the attenuation of the STAT5 signaling axis. Additionally, OMT was found to abrogate STAT5 activation through multiple mechanisms(s), whereas matrine exhibited a minimal effect on the STAT5 signaling cascade.

\section{Results}

\subsection{OMT Suppresses Constitutive STAT5 Phosphorylation in NSCLC Cells}

Several previous studies have shown that STAT5 plays a significant role in regulating tumor survival and proliferation [22,31,88-90]. We tested whether OMT can regulate constitutive STAT5 activation on A549 lung cancer cells. A549 cells were treated with various indicated concentrations for $6 \mathrm{~h}$ or time intervals with $200 \mu \mathrm{M}$ OMT. As shown on Figure 1B,C, constitutive phosphorylation of STAT5 was markedly suppressed upon OMT exposure.

\subsection{OMT Inhibits STAT5 DNA Binding and Nuclear Translocation}

Because STAT5 dimerization is accompanied by subsequent translocation into the nucleus and the transcription of target genes, we examined whether OMT can inhibit STAT5 binding to DNA by EMSA. The result shows that OMT can indeed inhibit STAT5-DNA binding (Figure 1D) in a dose- and time-dependent fashion. Dimerized STAT5 can translocate into the nucleus to regulate gene transcription. Therefore, we examined whether OMT can suppress STAT5 translocation by immunocytochemistry. The results show that the translocation of STAT5 into nucleus was modulated by OMT (Figure 1E).

\subsection{OMT Suppresses the Phosphorylation of Signaling Kinases}

Because STAT5 has been activated by upstream signaling kinases, we examined that OMT can also suppress the phosphorylation of JAK1, JAK2, and Src. Cells were treated, and OMT suppressed phospho-JAK1, phospho-JAK2, and phospho-Src, both in dose- and time-dependent manners (Figure 1F,G). 
A.

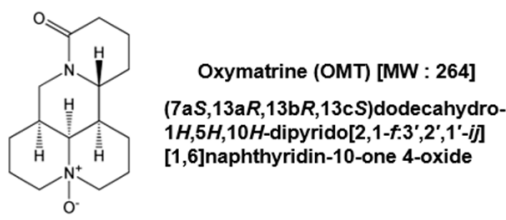

B.

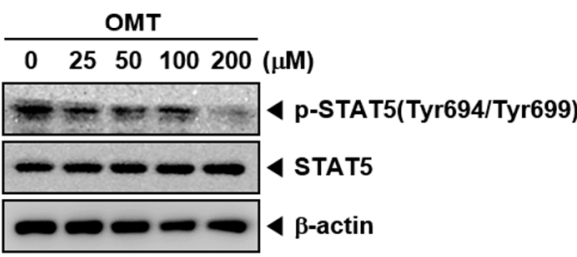

D.

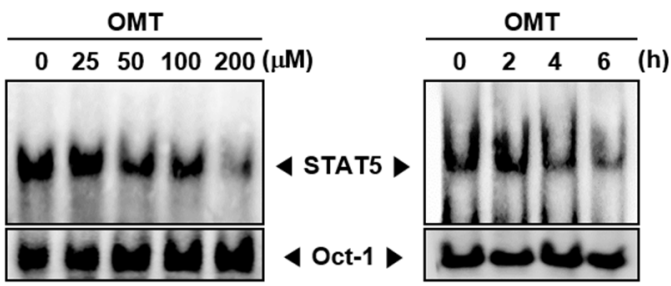

F.

OMT

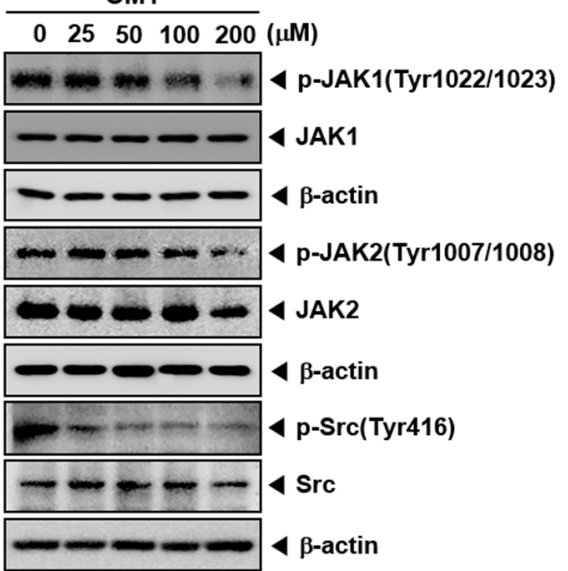

C.

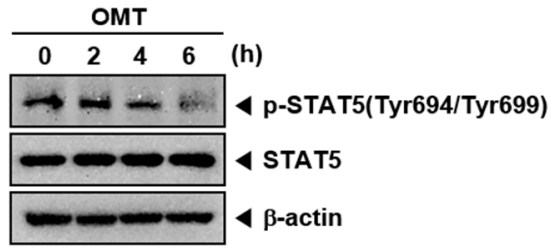

E.

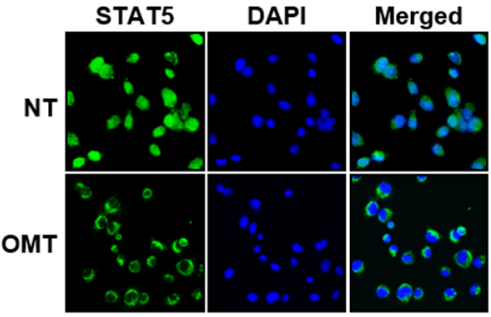

G.

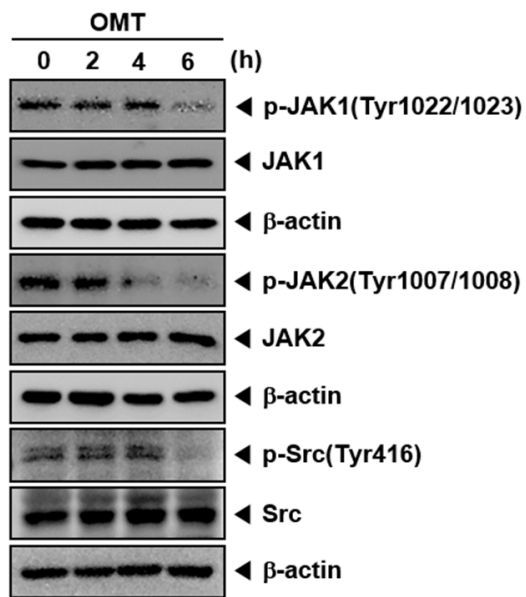

Figure 1. Oxymatrine (OMT) inhibits the constitutive STAT5 phosphorylation in A549 human lung cancer cells. (A) The chemical structure of OMT and matrine. (B,C) OMT inhibits STAT5 phosphorylation in dose- and time-dependent manners. A549 cells $\left(5 \times 10^{5}\right.$ cells/well) were treated with various concentrations $(0,25,50,100,200 \mu \mathrm{M})$ of OMT for $6 \mathrm{~h}$ or indicated a time interval with $200 \mu \mathrm{M}$ OMT. Then equal amounts of whole cell lysates was analyzed via Western blot analysis and probed for phospho-STAT5 (Tyr694/Tyr699) and STAT5. (D) OMT inhibits the binding activity of STAT5 in A549 cells. A549 cells ( $5 \times 10^{5}$ cells/well) were treated with OMT in the indicated dose- and time-dependent manners, and nuclear extracts were then analyzed by EMSA. (E) OMT suppressed the translocation of STAT5 to the nucleus. A549 cells $\left(2 \times 10^{4}\right.$ cells/well $)$ were treated with $200 \mu \mathrm{M}$ OMT for $6 \mathrm{~h}$, and the intracellular activity of STAT5 was then analyzed by immunocytochemistry. $(\mathbf{F}, \mathbf{G})$ OMT inhibits phosphorylation of upstream kinases. Western blot was performed as shown in Figure 1B,C, and levels of various proteins was analyzed. 
2.4. OMT Abrogates the Activation of IL-6-Induced STAT5 Phosphorylation and the Activation of Upstream Kinases

We also examined whether OMT also has a modulatory effect on the inducible STAT5, and upstream signaling kinases in H1299 cells. Cells were pretreated with OMT, and STAT5 phosphorylation was then induced by IL-6 treatment. As shown on Figure 2A-C, OMT clearly suppressed phosphorylation of STAT5 and attenuated JAK1, JAK2, and Src activation.

\subsection{OMT Exhibits a Substantial Inhibitory Effect on the Phosphorylation of STAT5 as Compared to Matrine}

OMT and matrine have very similar chemical structures, but matrine has one less oxygen. We next determined the effect of martine on phospho-STAT5 expression in NSCLC cells. As shown in Figure 2D,E, OMT exhibited substantial suppressive effects on constitutive and inducible phospho-STAT5 expression in A549 and H1299 cells, respectively.

A.

\begin{tabular}{|c|c|c|c|c|c|}
\hline & & OMT & "/IL-6 & & \\
\hline 0 & 0 & 2 & 4 & 6 & (h) \\
\hline$\rightarrow$ & 7 & - & - & + & 4 p-STAT5(Tyr694/Tyr699) \\
\hline - & - & - & - & - & 4 STAT5 \\
\hline & - & & - & - & $\beta$-actin \\
\hline
\end{tabular}

B.

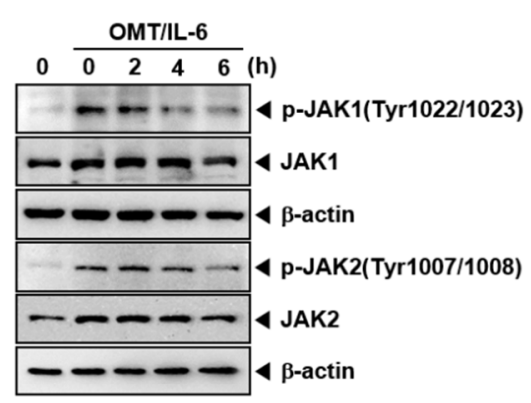

C.

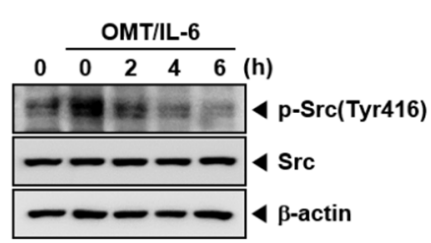

D.

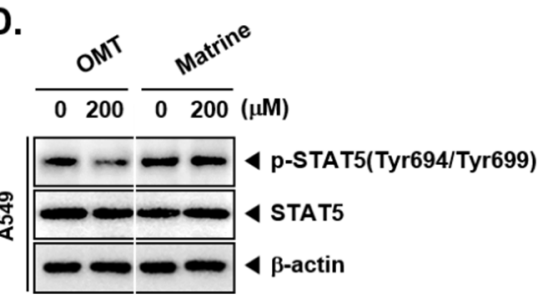

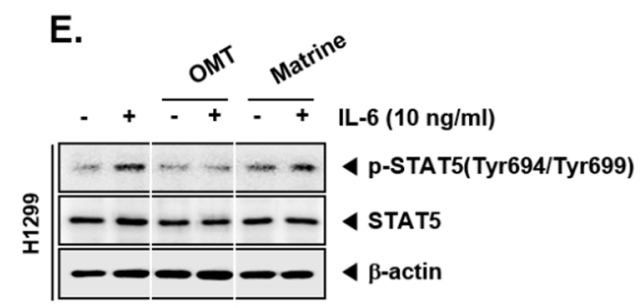

Figure 2. OMT can downregulate inducible STAT5 phosphorylation in H1299 cells. (A-C) H1299 cells $\left(5 \times 10^{5}\right.$ cells $/$ well) were treated with $200 \mu \mathrm{M}$ OMT for indicated time intervals and then treated with IL-6 $(10 \mathrm{ng} / \mathrm{mL})$ for $15 \mathrm{~min}$. Western blot analysis was performed as shown in Figure 1B,C. (D) A549 cells $\left(5 \times 10^{5}\right.$ cells / well) were treated with OMT or matrine $(200 \mu \mathrm{M})$ for $6 \mathrm{~h}$. Equal amount of whole cell lysates were prepared, and Western blot analysis was performed as shown in Figure 1B,C. (E) H1299 cells $\left(5 \times 10^{5}\right.$ cells/well) were treated with OMT or matrine $(200 \mu \mathrm{M})$ for $6 \mathrm{~h}$ and then treated with IL-6 $(10 \mathrm{ng} / \mathrm{mL})$ for $15 \mathrm{~min}$. Western blot analysis was performed as shown in Figure 1B,C.

\subsection{OMT Suppresses the Expression of Various Oncogenic Proteins and Induces Cell Death in NSCLC Cells}

STAT5 activation can regulate various oncogenic proteins involved in cell proliferation, cell survival, and angiogenesis. Western blot analysis indicates that OMT-treated cells showed a reduction in the levels of Bcl-2, Bcl-xl, Survivin, IAP-1, IAP-2, COX-2, VEGF, and MMP-9 proteins (Figure 3A). Furthermore, anti-apoptotic protein expression was also suppressed at their mRNA levels 
upon OMT exposure (Figure 3B). We also found that caspase-3 and PARP cleavage was induced upon the OMT treatment in A549 cells (Figure 3C). As shown in Figure 3D, OMT-treated cells were arrested in the Sub G1 and G0/G1 phase. The Sub G1 phase population was 7\% in non-treated cells and then increased to 12 and $21 \%$ in cells treated with 100 and $200 \mu \mathrm{M}$ OMT. Additionally, both A549 cells and H1299 cells showed positive staining for Annexin V upon $200 \mu$ M OMT treatment (Figure 3E,F). To analyze the effect on cell growth, an MTT assay was used and the growth potential of both A549 and H1299 cells was found to be significantly abrogated (Figure 3G).

A.

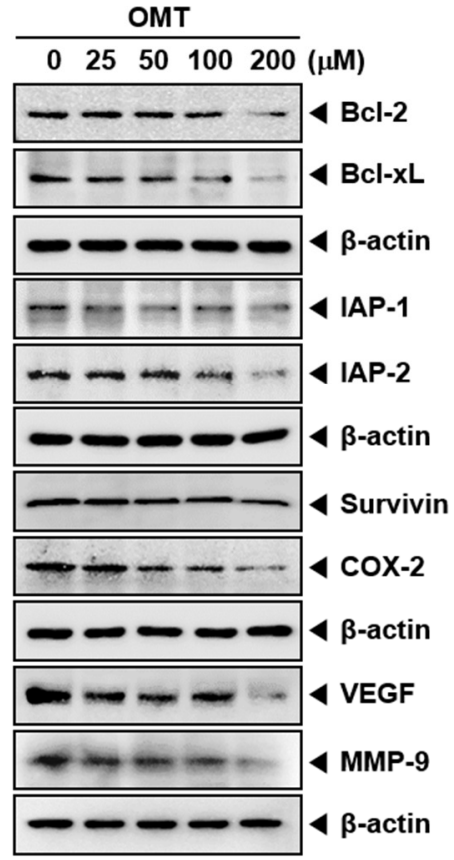

D.
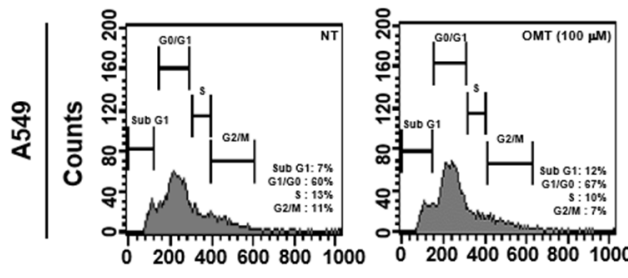

E.
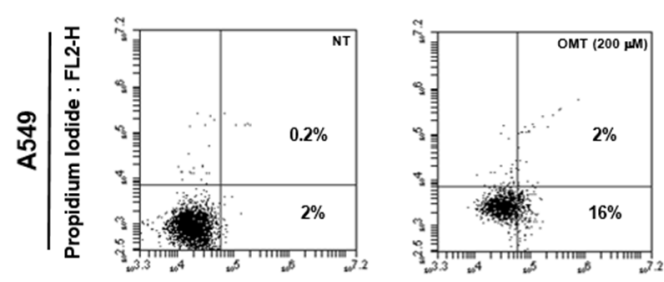

Annexin V : FL1-H
B.

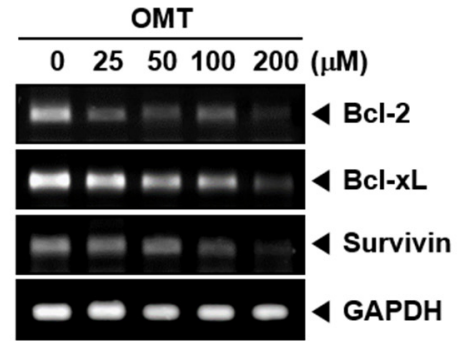

c.

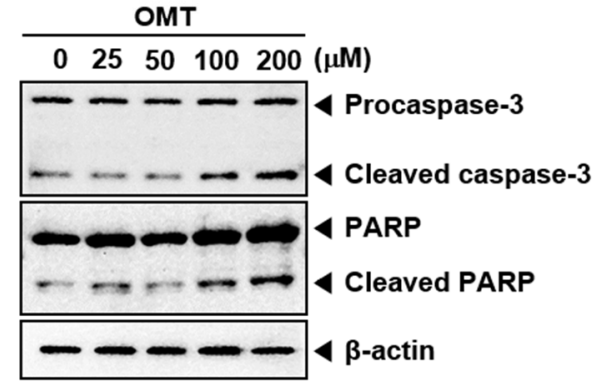

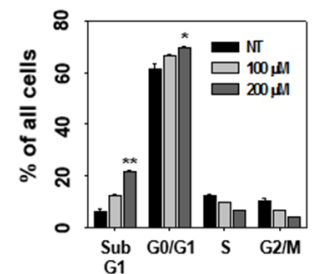

F.
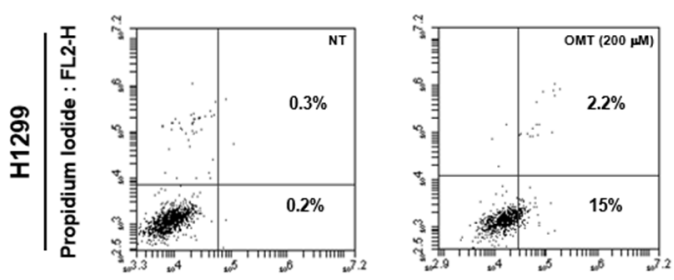

Annexin V : FL1-H

Figure 3. Cont. 


\section{G.}

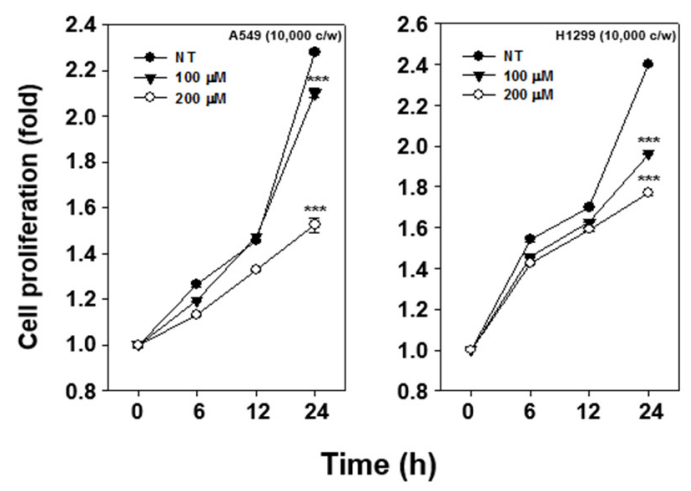

Figure 3. OMT promotes apoptosis in A549 cells and H1299 cells. (A) OMT can downregulate levels of anti-apoptotic proteins such as Bcl-2, Bcl-xl, Survivin, IAP-1, IAP-2, COX-2, VEGF, and MMP-9. A549 cells $\left(5 \times 10^{5}\right.$ cells/well) were treated with OMT in indicated concentrations for $24 \mathrm{~h}$. Whole cell lysates were prepared with the same amount and analyzed via Western blot analysis. (B) A549 cells $\left(5 \times 10^{5}\right.$ cells / well $)$ were treated with various concentrations of OMT for $24 \mathrm{~h}$. Total RNA was extracted, and equal amounts were examined for expression of Bcl-2, Bcl-xl, and Survivin by RT-PCR. (C) Whole cell lysates were prepared with the same amount, and expression of the proteins was analyzed via Western blot analysis. (D) A549 cells $\left(5 \times 10^{5}\right.$ cells/well) were treated with OMT $(0,100,200 \mu \mathrm{M})$ for $24 \mathrm{~h}$. Cells were digested with RNase A for $1 \mathrm{~h}$ and stained with propidium iodide, and cell cycle division was analyzed with flow cytometric analysis. The results are presented as the mean \pm SE. The experiments were performed three times independently. ${ }^{*} p<0.05$ and ${ }^{* *} p<0.01$ compared to the control. (E,F) A549 cells $\left(5 \times 10^{5}\right.$ cells/well) and H1299 cells $\left(5 \times 10^{5}\right.$ cells/well) were treated with OMT $(200 \mu \mathrm{M})$ for $24 \mathrm{~h}$. After treatment, cells were stained with Annexin V-FITC and then analyzed by flow cytometry. (G) OMT inhibited cell growth. A549 cells $\left(1 \times 10^{4}\right.$ cells/well $)$ and H1299 cells $\left(1 \times 10^{4}\right.$ cells/well $)$ were treated with $\operatorname{OMT}(0,100,200 \mu \mathrm{M})$ for indicated time intervals. Cell viability was analyzed by MTT assay. The results are presented as the mean $\pm \mathrm{SE}$. The experiments were performed three times independently. ${ }^{* *} p<0.001$ compared to the control.

\subsection{Combination Treatment of OMT and Paclitaxel Exhibits Significant Anti-Cancer Effects}

We carried out cytotoxicity analysis and determined optimal concentrations using Calcusynsoftware (BIOSOFT, Ferguson, MO). A549 cells were incubated with a range of concentrations of OMT as well as paclitaxel and cell viability was determined by MTT assay. When incubated for $24 \mathrm{~h}, \mathrm{OMT}$ and paclitaxel in combination exerted significant cytotoxicity in a concentration-dependent manner (Figure 4A). We found that the combination of $100 \mu \mathrm{M}$ OMT and $10 \mathrm{nM}$ paclitaxel exerted a substantial potentiation effect $(C I=0.742)$. For this reason, the combination of $100 \mu \mathrm{MOMT}$ and $10 \mathrm{nM}$ paclitaxel was used further to determine the possible mechanism of chemosensitazation of NSCLC cells to paclitaxel upon OMT treatment. As shown in Figure 4B, OMT and paclitaxel co-treatment induced significant apoptosis as compared to the single treatment. We then analyzed the activation of STAT5 and upstream signaling kinases via Western blot analysis. The results indicated that STAT5 and upstream signaling kinases JAK1, JAK2, and Src phosphorylation was also substantially reduced by OMT and paclitaxel treatment (Figure 4C,D). The effect of drug combination on apoptosis was analyzed next. The results indicated that OMT and paclitaxel co-treatment substantially enhanced apoptosis, as observed in multiple assays (Figure 5A,B). Furthermore, we found that the expression of various oncogenic proteins was substantially suppressed by OMT and paclitaxel co-treatment (Figure 5C,D). The result also indicated that OMT and paclitaxel co-treatment induced a more effective increase in caspase-3 and PARP cleavage as compared to the individual agents (Figure 5D). 
A.
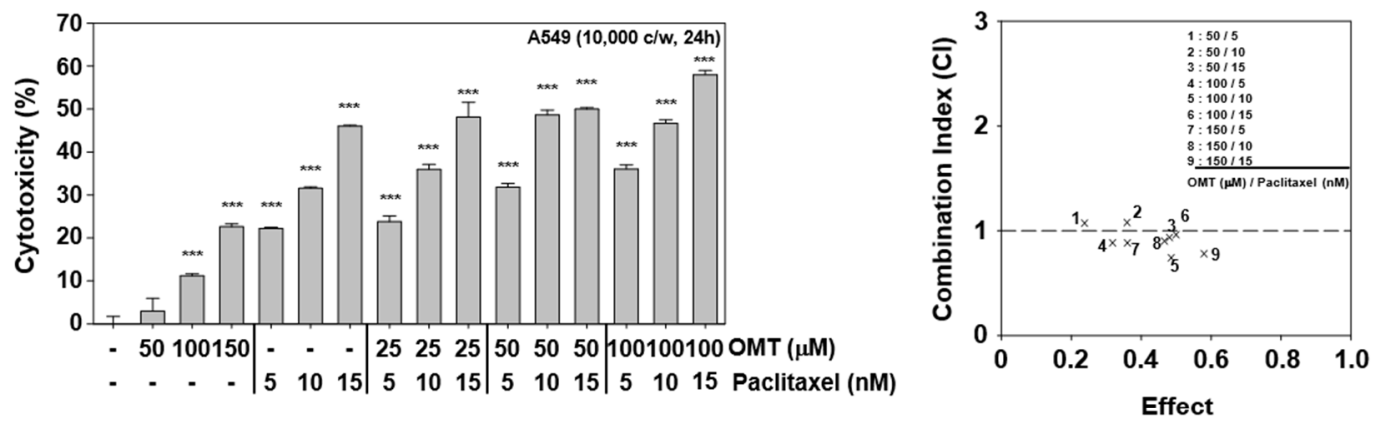

B.
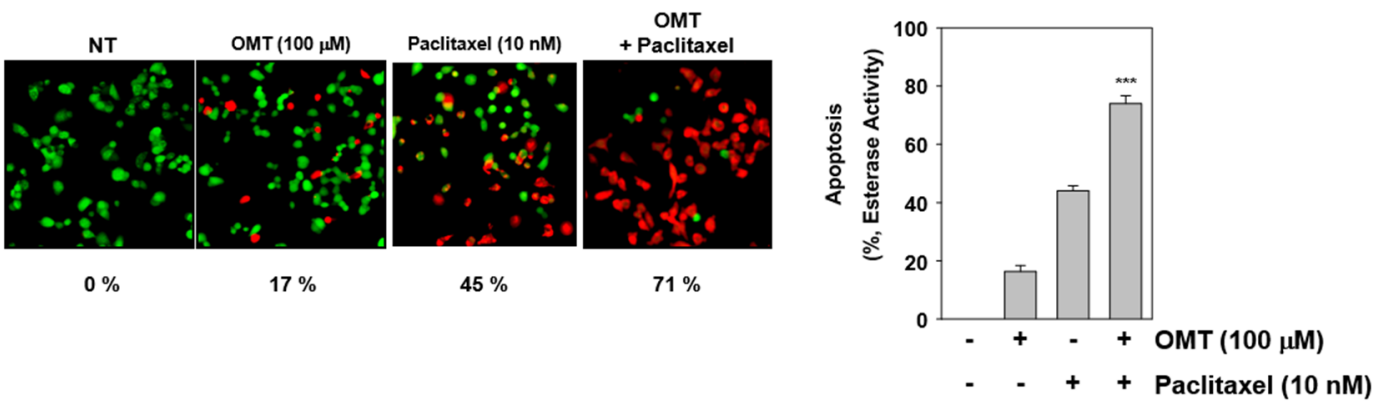

C.

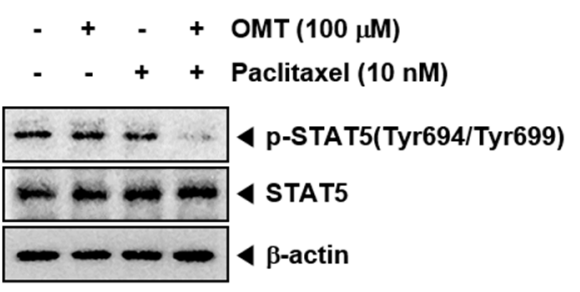

D.

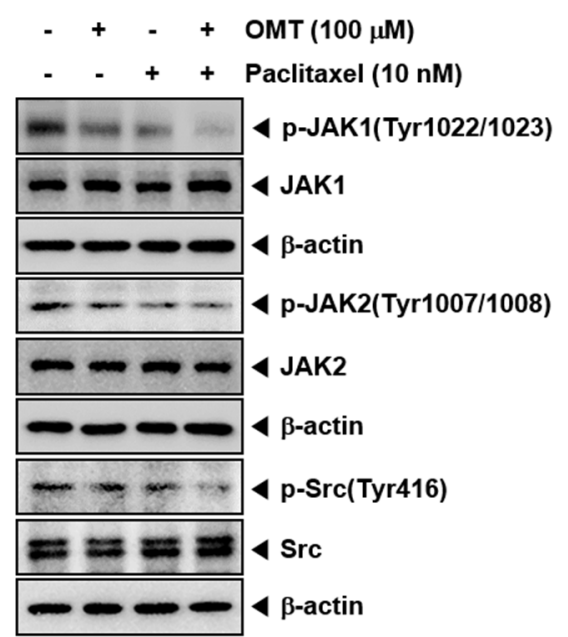

Figure 4. OMT and paclitaxel can enhance cytotoxicity in A549 cells. (A) Cytotoxicity of OMT and paclitaxel were analyzed by MTT assay. A549 cells $\left(1 \times 10^{4}\right.$ cells/well $)$ were treated with OMT and paclitaxel in various concentrations for $24 \mathrm{~h}$. The average of $\mathrm{CI}$ values about various combination indicates that the best combination ratio was that of $100 \mu \mathrm{M}$ OMT and $10 \mathrm{nM}$ paclitaxel. (B) Cytotoxicity of OMT and paclitaxel were analyzed using a Live and Dead assay. A549 cells $\left(2 \times 10^{4}\right.$ cells/well $)$ were treated with $100 \mu \mathrm{M}$ OMT and $10 \mathrm{nM}$ paclitaxel for $24 \mathrm{~h}$. Live cells were stained in green and dead cells were stained in red. The graph (right) shows the rate of dead cells by quantification. The results are presented as the mean \pm SE. The experiments were performed three times independently. ${ }^{* * *} p<0.001$ compared to the control. (C,D) A549 cells $\left(5 \times 10^{5}\right.$ cells/well) were treated with $100 \mu \mathrm{M}$ OMT and $10 \mathrm{nM}$ paclitaxel for $6 \mathrm{~h}$. The Western blot experiments were carried out as shown above in Figure 1B,C. 
A.
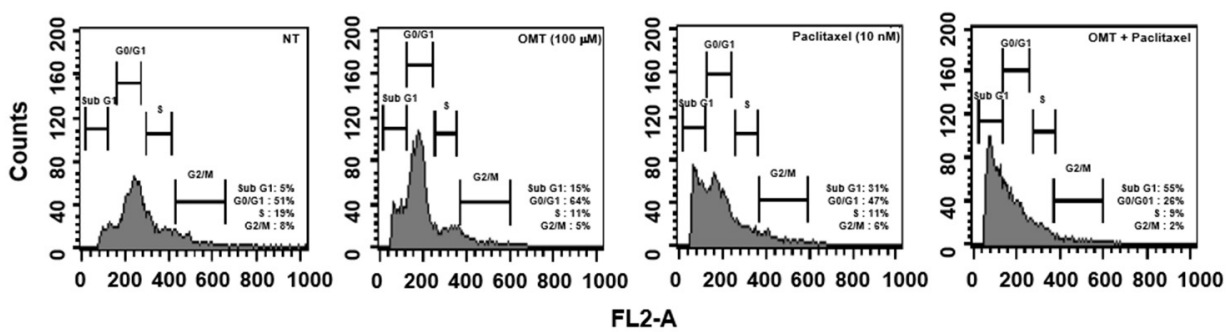

FL2-A

B.
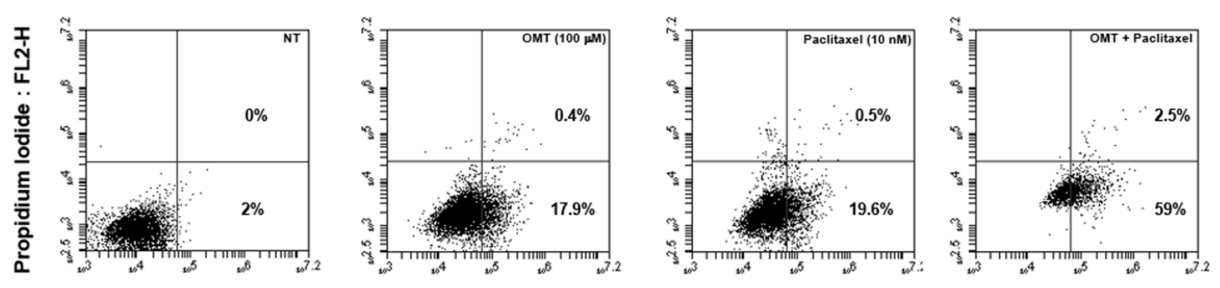

Annexin V : FL1-H

C.

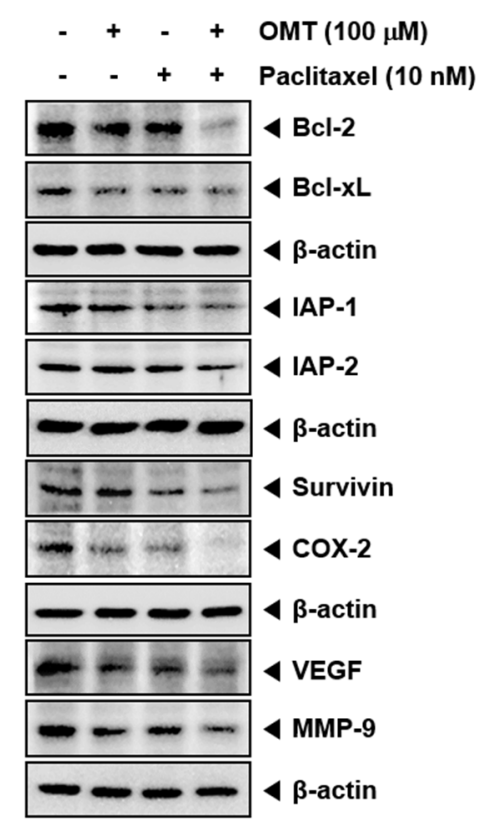

D.

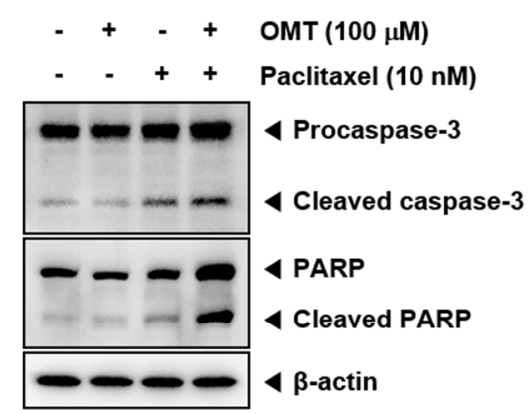

Figure 5. OMT and paclitaxel can induce substantial apoptosis. (A) A549 cells ( $5 \times 10^{5}$ cells/well) were treated with OMT $(100 \mu \mathrm{M})$ and paclitaxel $(10 \mathrm{nM})$ for $24 \mathrm{~h}$ and then incubated with RNase A for $1 \mathrm{~h}$. Cells were stained with propidium iodide, analyzed by flow cytometry. (B) OMT (100 $\mu \mathrm{M})$ - and paclitaxel (10 nM)-treated A549 cells were stained with Annexin V-FITC and propidium iodide and analyzed by flow cytometry. (C,D) A549 cells $\left(5 \times 10^{5}\right.$ cells / well) were treated with OMT $(100 \mu \mathrm{M})$ and paclitaxel $(10 \mathrm{nM})$ for $24 \mathrm{~h}$. Equal amount of whole cell lysates were analyzed via Western blot analysis for various proteins. 
2.8. OMT Induces Antitumor Effects in a Xenograft Mouse Model and Modulates STAT5 Activation in Tumor Tissues

We examined the pharmacological potential of OMT on the growth of subcutaneously implanted human lung cancer cells A549 in nude mice. The experimental protocol is specified in Figure 6A. In Group I, as the control group, tumor volume sharply increased. However, Groups II, III, and IV had only a marginal increase in tumor volume (Figure 6C). On Day 25, animals were sacrificed, and final tumor size and tumor weight were measured. Tumor size and weight were significantly decreased in Groups II, III, and IV as compared to the control group (Group I) (Figure 6B,D). However, OMT and paclitaxel treatment had no effects on the body weight of mice (Figure $6 \mathrm{E}$ ). We also analyzed the effect of OMT and paclitaxel co-treatment on A549 human lung tumor tissues by immunohistochemical analysis and found that co-treatment of OMT reduced phospho-STAT5 expression. Moreover, the data showed that OMT also downregulated the expression of Ki-67 protein, which is a biomarker of proliferation (Figure 7A). Additionally, we investigated whether OMT and paclitaxel can regulate STAT5 expression in A549 tumor tissues. Interestingly, OMT and paclitaxel were found to significantly decrease the expression level of phospho-STAT5, but there was no change in the levels of total STAT5 protein (Figure 7B). In order to determine whether OMT can suppress various proteins related with anti-apoptosis, proliferation, and angiogenesis, we carried out Western blot analysis using tumor tissues proteins. The results indicate that Bcl-2, Bcl-xl, Survivin, IAP-1, IAP-2, COX-2, VEGF, and MMP-9 protein levels were significantly reduced upon OMT and paclitaxel treatment (Figure 7C). Additionally, OMT was found to induce substantial expression of caspase- 3 and cause PARP cleavage (Figure 7D).

A.

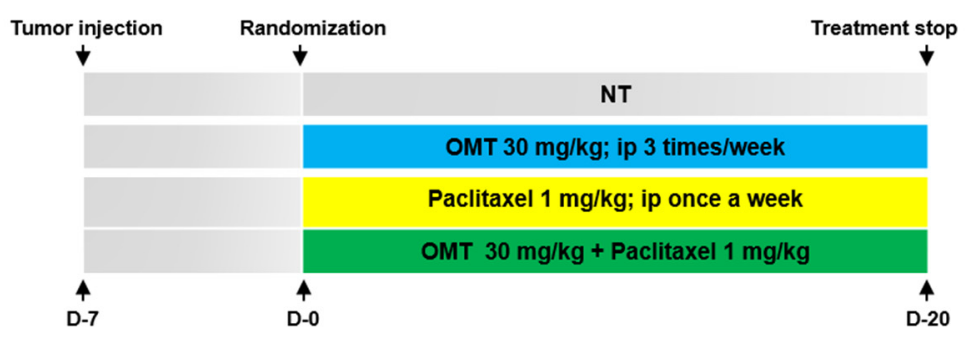

B.
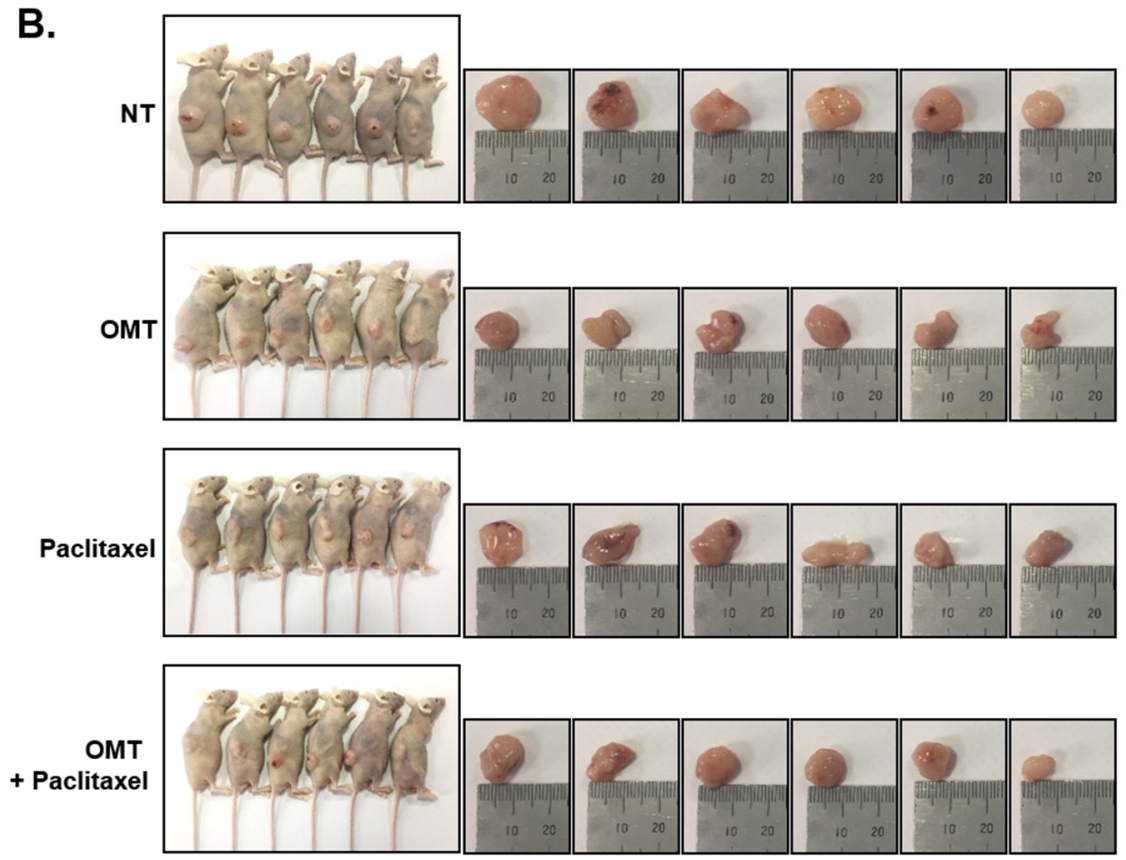

Figure 6. Cont. 
C.

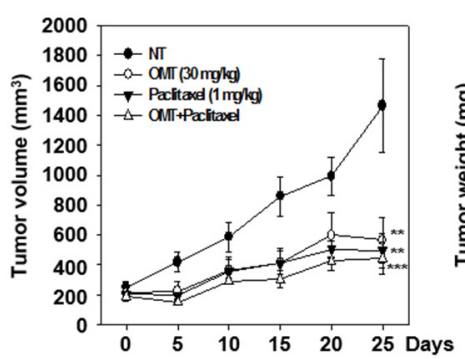

D.

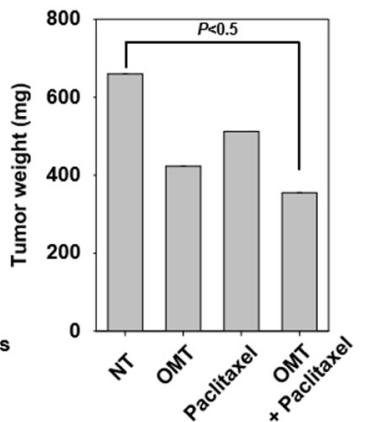

E.

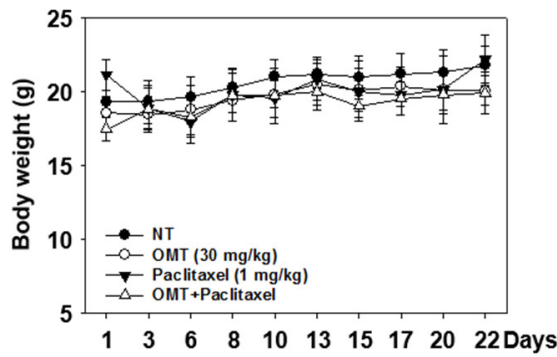

Figure 6. Anti-tumor effects of OMT and paclitaxel in a human lung cancer xenograft mouse model. (A) A549 cells $\left(1 \times 10^{7}\right.$ cells $/$ mice $)$ were injected subcutaneously into the right flank of the mice. After 1 week of tumor cell injection, the animals were randomized into four groups. Group I was treated with PBS (100 $\mu$ L; i.p.; 3 times/week), Group II was treated with OMT alone ( $30 \mathrm{mg} / \mathrm{kg}$; i.p.; 3 times/week), Group III was treated with paclitaxel alone ( $1 \mathrm{mg} / \mathrm{kg}$; i.p.; once a week), and Group IV was treated with a combination of OMT (30 mg/kg; i.p.; 3 times/week) and paclitaxel ( $1 \mathrm{mg} / \mathrm{kg}$; i.p.; once a week) $(n=6)$. (B) Necropsy photographs of mice and xenograft tumors of A549 cells on Day 25. (C) Tumor volume was measured using Digimatic calipers on the indicated every 5 days (mean $\pm \mathrm{SE}$ ). ${ }^{* *} p<0.01$ and ${ }^{* * *} p<0.001$ compared to the control. (D) Tumor weight was measured on Day 25 , the last day of the experiment (mean \pm SE). (E) Body weight was measured on the indicated days. $\mathrm{OMT}$ and paclitaxel combination treatment did not exhibit significant toxicity in mice (mean $\pm \mathrm{SE}$ ).

A.

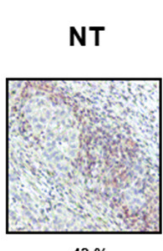

$43 \%$

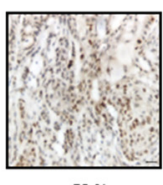

$58 \%$

\section{OMT}

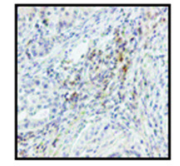

$29 \%$

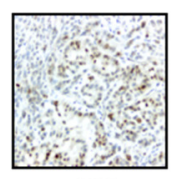

$16 \%$

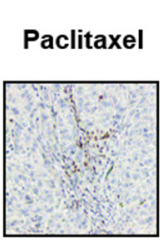

$20 \%$

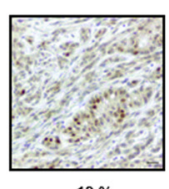

$13 \%$
OMT

+ Paclitaxel
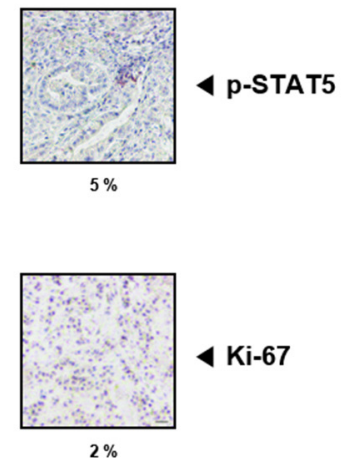
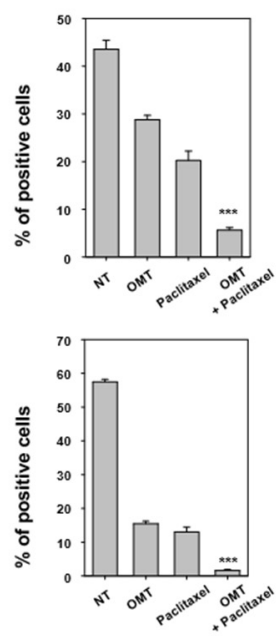

B.
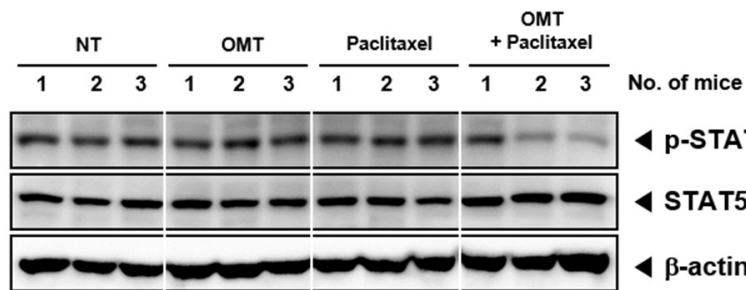

p-STAT5(Tyr694/Tyr699)

4 STAT5

$\beta$-actin

Figure 7. Cont. 


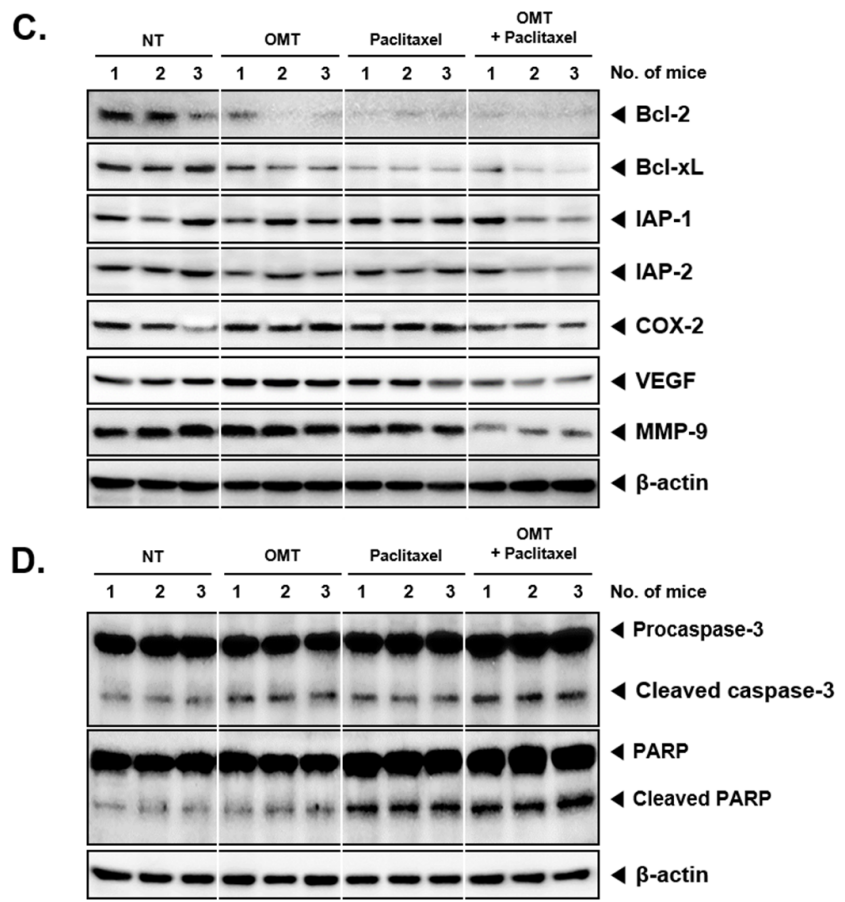

Figure 7. Effect of drug combination on cell proliferation, survival, and angiogenesis in lung cancer tissues. (A) OMT- and paclitaxel-treated mice tissues were analyzed by immunohistochemical analysis. Phospho-STAT5, and Ki-67 levels were detected in each treatment group and represented data were shown on the left panel. Solid tumors from the control and various treatment groups were fixed with $10 \%$ phosphate buffered formalin, processed, and embedded in paraffin. Sections were cut and deparaffinized in xylene and dehydrated in graded alcohol and finally hydrated in water. Antigen retrieval was performed by boiling the slide in $10 \mathrm{mM}$ sodium citrate (pH 6.0) for $30 \mathrm{~min}$. Immunohistochemistry was performed following manufacturer instructions (Vector Laboratories ImmPRESS ${ }^{\mathrm{TM}}$ REAGENT KIT). Quantification of phospho-STAT5 and the Ki-67 index was represented as mean \pm SE on right panel. ${ }^{* * *} p<0.001$ compared to the control. (B) Western blot analysis with tissues samples showed that OMT and paclitaxel inhibited phospho-STAT5 (Tyr694/Tyr699). (C,D) Equal amount of lysates were analyzed via Western blot analysis and then probed for different proteins. The results shown are representative of two independent experiments.

\section{Discussion}

The goal of this study was primarily to determine the anti-cancer effects of oxymatrine in NSCLC cells and decipher its underlying molecular mechanism(s) of action. STAT families of proteins are often found to be deregulated in lung cancer cells [31,88-90]. In addition to the detection of hyperactivated STAT3 transcription factor in cancer cells, other studies have highlighted the importance of another member of the STAT family, namely STAT5, which has been reported to be frequently activated by various tyrosine kinases, oxidant stress, and ROS metabolism in cancer [91]. In prostate cancer cells, STAT5 acts as a marker for disease recurrences, and detection of high nuclear phosphorylated STAT5 is an indicator of both early recurrence and shorter overall survival [92]. Interestingly, in 71 NSCLC patients, immunoexpression analysis revealed significantly higher STAT5 levels in pT2 tumors and a positive correlation between STAT5 and COX-2 levels were also observed [88,89]. Moreover, immunohistochemical analysis for the expression of STAT5 was carried out in 92 NSCLC samples. It was noted that STAT5 was found to be overexpressed in $41.3 \%$ in the cytoplasm and $32.6 \%$ in the nucleus and was correlated with Bcl-xL overexpression [90].

Natural and synthetic compounds have been shown to inhibit upstream kinases involved in the STAT5 signaling pathway. For example, a small molecular weight compound containing a phosphotyrosyl-mimicking salicylic acid group has been shown to efficiently bind to the SH2 
domain of STAT5 and inhibit STAT5-SH2 domain protein interactions in leukemic cells [93]. There are also several molecules that have been shown to inhibit STAT5 phosphorylation and inhibit leukemia cell proliferation [94-97]. Some recent studies have also reported that natural pharmacological agents such as formononetin can modulate the STAT5 signaling pathway in multiple myeloma cells, and these compounds may have tremendous potential in the prevention and therapy of cancer [39-44]. Indeed, the discovery of several novel small-molecule drugs that target JAK-STAT5 are in progress, although at present no specific STAT5 inhibitors are available for testing in clinical trials. It is well known that IL-6 can activate the early acute phase response by activating STAT3 (Tyr705) and STAT5 (Tyr694/Tyr699) signaling pathways and plays an important role in diseases associated with chronic inflammation, including cancer development [31,98-100]. It has been previously reported that OMT can exhibit significant anti-cancer effects on a variety of tumor cells by modulation of multiple signaling pathways. In this study, we report for the first time that OMT exhibits potent anti-cancer activity by abrogating the STAT5 signaling pathway in NSCLC cells. We demonstrate that OMT suppressed the constitutive and IL-6 induced phosphorylation of STAT5 in A549 and H1299 cells along with the concomitant suppression of JAKs and c-Src kinases. Interestingly, we noted that matrine, which is quite identical to OMT in its chemical structure, exhibited its inhibitory effect on STAT5 phosphorylation to a lesser extent as compared to OMT. The OMT-mediated modulation of the STAT5 signaling axis was associated with the inhibition of the proliferation and induction of apoptosis in NSCLC cells. Therefore, the findings suggest that OMT could be an effective and novel inhibitor of STAT5 phosphorylation, DNA binding, and subsequent nuclear translocation in NSCLC cells. The underlying molecular mechanism(s) by which OMT can affect STAT5 activation was also investigated in detail. STAT5 can interact with JAK1/2 kinases as a scaffold, and this interaction often leads to STAT5 phosphorylation at Tyr694/Tyr699 residues. Besides attenuating JAK1/2 activation, OMT also inhibited c-Src phosphorylation involved in STAT5 activation in tumor cells. Therefore, we can conclude that OMT can regulate STAT5 activation by repressing the phosphorylation of JAK1/2 and Src proteins.

We also report that sub-optimal concentration of OMT when used in combination with a low dose of mitotic inhibitor paclitaxel produced significant anti-cancer effects in NSCLC cells by abrogating proliferation and causing downregulation in the expression of various oncogenic proteins. In addition, paclitaxel was found to induce phosphorylation of STAT5 and its upstream kinases. OMT also dose-dependently inhibited paclitaxel-induced phosphorylation of STAT5, JAK1/2, and activated caspase 3. Our findings also clearly show that OMT can negatively regulate STAT5 protein, resulting in the inhibition or proliferation and augmentation of apoptosis induced by chemotherapy in lung cancer cells. In a recent study, Liu et al. reported that OMT enhanced the inhibitory effect of 5-fluorouracil on hepatocellular carcinoma both in vitro and in vivo [55]. A similar study reported by the same group showed that OMT also augmented the anti-tumor activity of oxaliplatin in colon cancer cells [60]. In our preclinical study, OMT at a dose of $30 \mathrm{mg} / \mathrm{kg}$ when administered intraperitoneally (i.p.) thrice a week for 20 days did not induce a significant change in lung tumor volume. However, when used in combination with paclitaxel, the combination group produced a significant reduction in tumor volume. Overall, our results suggest that OMT in combination with paclitaxel can significantly inhibit lung cancer cell growth both in vitro and in vivo. Similarly, in a recent study, Wei Li et al. showed that OMT can inhibit the activation of both wild-type and mutant epidermal growth factor receptor in NSCLC. Moreover, OMT prominently suppressed tumor growth in a xenograft mouse model [76]. Thus, OMT appears to function as a novel therapeutic agent that can be effectively employed for the treatment of various malignancies.

\section{Materials and Methods}

\subsection{Reagents}

Oxymatrine (OMT, Figure 1A) was purchased from Cayman Chemical (Michigan, USA) and matrine was purchased from Sigma-Aldrich (St. Louis, MO, USA). OMT was stored in a $100 \mathrm{mM}$ stock 
solution with dimethyl sulfoxide at $-20^{\circ} \mathrm{C}$, diluted in the cultured media for in vitro or PBS in vivo experiments. 3-(4,5-Dimethylthiazol-2-yl)-2,5-diphenyltetrazolium bromide (MTT), propidium iodide (PI), Tris base, glycine, $\mathrm{NaCl}$, sodium dodecylsulfate (SDS), and bovine serum albumin (BSA) were purchased from Sigma-Aldrich (St. Louis, MO, USA). LightShift ${ }^{\circledR}$ Chemiluminescent EMSA kit were purchased from Thermo Fisher Scientific Inc (Waltham, MA, USA). Alexa Fluor ${ }^{\circledR} 488$ donkey anti-rabbit $\operatorname{IgG}(\mathrm{H}+\mathrm{L})$ antibody was obtained from Life Technologies (Grand Island, NY, USA). Whole-cell lysates of tumor tissues were obtained with T-PER Tissues Protein Extraction Reagent (Pierce, Rockford, IL, USA).

\subsection{Cell Lines and Culture Conditions}

Human non-small cell lung carcinoma (NSCLS) cells A549 and H1299 cells were obtained from American Type Culture Collection (Manassas, VA, USA). A549 cells were cultured with DMEM-low medium containing $10 \%$ inactivated fetal bovine serum (FBS) and $1 \%$ penicillin-streptomycin. Cells were incubated at $37^{\circ} \mathrm{C}$ in $5 \% \mathrm{CO}_{2}$ conditions.

\subsection{Western Blot Analysis}

Western blot analysis was performed as described previously [101].

\subsection{Electrophoretic Mobility Shift Assay (EMSA) for STAT5-DNA Binding}

STAT5-DNA binding was analyzed by an electrophoretic mobility shift assay (EMSA) as described previously [102].

\subsection{Immunocytochemistry for STAT5 Localization}

Immunocytochemistry was performed as described previously [103].

\subsection{Reverse Transcription Polymerase Chain Reaction (RT-PCR) for RNA Analysis}

A549 cells were treated with various concentrations of OMT $(0,25,50,100,200 \mu \mathrm{M})$ for $24 \mathrm{~h}$. Cells were harvested, suspended in trizol, and then incubated with chloroform and isopropanol. Extracted RNA was reverse-transcribed into cDNA and examined by RT-PCR using superscript reverse transcriptase and Taq polymerase (TAKARA, Tokyo, Japan). RT-PCR was performed with Bcl-2 at $94{ }^{\circ} \mathrm{C}$ for $2 \mathrm{~min}, 94{ }^{\circ} \mathrm{C}$ for $15 \mathrm{~s}, 56^{\circ} \mathrm{C}$ for $30 \mathrm{~s}$, and $72{ }^{\circ} \mathrm{C}$ for $1 \mathrm{~min}$, with 30 cycles and an extension at $72{ }^{\circ} \mathrm{C}$ for $5 \mathrm{~min}$. Bcl-xl was performed at $94{ }^{\circ} \mathrm{C}$ for $2 \mathrm{~min}, 94{ }^{\circ} \mathrm{C}$ for $30 \mathrm{~s}, 56^{\circ} \mathrm{C}$ for $30 \mathrm{~s}$, and $72{ }^{\circ} \mathrm{C}$ for $1 \mathrm{~min}$, with 25 cycles and an extension at $72{ }^{\circ} \mathrm{C}$ for $7 \mathrm{~min}$. Survivin was performed at $94{ }^{\circ} \mathrm{C}$ for $5 \mathrm{~min}$, $94{ }^{\circ} \mathrm{C}$ for $30 \mathrm{~s}, 55^{\circ} \mathrm{C}$ for $30 \mathrm{~s}$, and $72{ }^{\circ} \mathrm{C}$ for $30 \mathrm{~s}$, with 30 cycles and an extension at $72{ }^{\circ} \mathrm{C}$ for $7 \mathrm{~min}$. Glyceraldehyde-3-phosphate dehydrogenase (GAPDH) was used as a control, and all experiments were performed at least three times as individual repeats.

\subsection{MTT Assay}

Cell proliferation was analyzed with an MTT assay. A549 cells and H1299 cells $\left(5 \times 10^{3}\right.$ cells $/$ well $)$ were seeded on a 96-well plate. Cells were treated with $\operatorname{OMT}(0,100,200 \mu \mathrm{M})$ for the indicated time intervals. After treatment, cells were treated with a $2 \mathrm{mg} / \mathrm{mL}$ MTT solution ( $30 \mu \mathrm{L} /$ well) for $2 \mathrm{~h}$ and a an MTT lysis buffer $(100 \mu \mathrm{L} /$ well $)$ was then added for overnight incubation at $37^{\circ} \mathrm{C}$. Finally, lysed MTT formazans were measured by VARIOSKAN LUX (Thermo Fisher Scientific Inc) at $570 \mathrm{~nm}$. Cell viability was normalized as relative percentages in comparison with untreated controls.

\subsection{Cell Cycle and Annexin V assays}

To confirm the apoptosis, we performed cell cycle analysis. A549 cells $\left(5 \times 10^{5}\right.$ cells / well) were treated with OMT alone or co-treated with paclitaxel in the indicated concentrations for $24 \mathrm{~h}$. Thereafter, cell cycle and annexin V assays were performed as described previously [104]. 


\subsection{Drug Combination Analyses with Paclitaxel and OMT}

To confirm the combination effect between $\operatorname{OMT}(0,50,100,150 \mu \mathrm{M})$ and paclitaxel $(0,5,10,15 \mathrm{nM})$, A549 cells $\left(1 \times 10^{4}\right.$ cells / well $)$ were seeded on a 96-well plate and treated with each concentration mixture for $24 \mathrm{~h}$. Cytotoxicity was analyzed by MTT assay to find the optimal dose of the drugs, and cells were then evaluated with CalcuSyn (BIOSOFT, Ferguson, MO, USA) software to calculate a combination index $(\mathrm{CI})$ and select a moderate combination rate. Using these data, synergy and antagonism were evaluated: $\mathrm{CI}<1, \mathrm{CI}=1$, and $\mathrm{CI}>1$, respectively.

\subsection{Live and Dead Assay}

A549 cells $\left(2 \times 10^{4}\right.$ cells/well $)$ were treated with OMT $(100 \mu \mathrm{M})$ and paclitaxel $(10 \mathrm{nM})$ for $24 \mathrm{~h}$. Cells were stained with $5 \mu \mathrm{M}$ Calcein AM and $5 \mu \mathrm{M}$ Ethd-1(Ethidium homodimer-1) at $37^{\circ} \mathrm{C}$ for 30 min using a Live and Dead assay (Invitrogen, Carlsbad, CA, USA). Because of the intracellular esterase activity, live cells disgregated the Calcein, so cells appeared in green. However, dead cells damaged the cellular membrane, so Ethd-1 could invade the cell and appeared in red. Stained cells were detected by an Olympus FluoView FV1000 confocal microscope (Tokyo, Japan).

\subsection{Animals}

All procedures involving animals were reviewed and approved by Kyung Hee University Institutional Animal Care and Use committee (KHUASP(SE)-17-130). Six-week-old athymic nu/nu female mice were purchased form Nara Biotec CO. (Gyeonggi-do, Korea).

\subsection{Experimental Protocol}

One week after tumor injection, tumor diameters were measured using a Digimatic caliper (Mitutoyo Company, Kawasaki, Japan). When tumors reached $0.25 \mathrm{~cm}$ in diameter, the mice were randomized into the following four treatment groups ( $n=6 /$ group). Group I, the control, was treated with PBS $(100 \mu \mathrm{L}$; i.p.; 3 times/week), Group II was treated with OMT alone ( $30 \mathrm{mg} / \mathrm{kg}$; i.p.; 3 times/week), Group III was treated with paclitaxel alone ( $1 \mathrm{mg} / \mathrm{kg}$; i.p.; once a week), and Group IV was treated with both OMT (30 mg/kg; i.p.; 3 times/week) and paclitaxel (1 mg/kg; i.p.; once a week). Therapy continued for 20 days from randomization (Day 0 ). Tumor volumes were measured by the Digimatic caliper every 5 days, and mouse body weight was measured in $2 \sim 3$ day intervals. Mice were killed 5 days after last therapy. Tumors were excised, and final weight and volume was measured using the formula $V=4 / 3 \pi r^{3}$. Half of the tumor tissues were fixed in formalin and embedded in paraffin for immunohistochemistry and routine hematoxylin and eosin (H\&E) staining. The other half was snap-frozen in liquid nitrogen and stored at $-80^{\circ} \mathrm{C}$.

\subsection{Western Blot and Immunohistochemical Analysis of Tumor Tissues}

These assays were performed as described previously [39].

\subsection{Statistical Analysis}

All numeric values are represented as the mean \pm SE. Statistical significance of the data compared with the untreated control was determined using the Mann-Whitney $U$ test. Significance was set at $p<0.05$.

\section{Conclusions}

We report here that OP-D can potentiate paclitaxel-induced apoptotic effects, leading to the downregulation of STAT5 activation, and thus may be used in combination with chemotherapeutic agents against NSCLC. 
Author Contributions: G.S. and K.S.A. conceived the study and provided the project direction. Y.Y.J. and M.K.S. guided and performed the experiments, analyzed the data, and wrote the manuscript until the final submission version. Y.Y.J. completed the cell experiments. Y.Y.J., C.K., and J.H.L. assisted in performing the animal experiments. A.S.N., O.A.N., B.E.B., G.S., and K.S.A. designed the experiments and revised the manuscript. All authors read and approved the final manuscript.

Funding: This work was supported by the National Research Foundation of Korea (NRF) grant funded by the Korean Government (MSIP) (NRF-2017M3A9E4065333 and 2018R1D1A1B07042969).

Conflicts of Interest: The authors declare no conflict of interest.

\section{Abbreviations}

STAT5 signal transducer and activator of transcription 5

JAK janus kinase

Src proto-oncogene tyrosine-protein kinase

TCM traditional Chinese medicine

NSCLC non-small cell lung carcinoma

NF- $\kappa$ B nuclear factor-kappaB

EMSA electrophoretic mobility shift assay

FBS fetal bovine serum

RT-PCR reverse Transcription Polymerase Chain Reaction

MTT (3-(4,5-dimethylthiazol-2-yl)-2,5-diphenyltetrazolium bromide

i.p. intraperitoneal injection

\section{References}

1. Siegel, R.; Naishadham, D.; Jemal, A. Cancer statistics, 2013. CA Cancer J. Clin. 2013, 63, 11-30. [CrossRef] [PubMed]

2. Herbst, R.S.; Morgensztern, D.; Boshoff, C. The biology and management of non-small cell lung cancer. Nature 2018, 553, 446-454. [PubMed]

3. Alberg, A.J.; Brock, M.V.; Ford, J.G.; Samet, J.M.; Spivack, S.D. Epidemiology of lung cancer: Diagnosis and management of lung cancer, 3rd ed: American College of Chest Physicians evidence-based clinical practice guidelines. Chest 2013, 143, e1S-e29S. [CrossRef] [PubMed]

4. Lee, J.H.; Kim, C.; Lee, S.G.; Yang, W.M.; Um, J.Y.; Sethi, G.; Ahn, K.S. Ophiopogonin D modulates multiple oncogenic signaling pathways, leading to suppression of proliferation and chemosensitization of human lung cancer cells. Phytomedicine 2018, 40, 165-175. [CrossRef] [PubMed]

5. Ko, J.H.; Nam, D.; Um, J.Y.; Jung, S.H.; Sethi, G.; Ahn, K.S. Bergamottin Suppresses Metastasis of Lung Cancer Cells through Abrogation of Diverse Oncogenic Signaling Cascades and Epithelial-to-Mesenchymal Transition. Molecules 2018, 23, 1601. [CrossRef] [PubMed]

6. Wang, L.; Syn, N.L.; Subhash, V.V.; Any, Y.; Thuya, W.L.; Cheow, E.S.H.; Kong, L.; Yu, F.; Peethala, P.C.; Wong, A.L.; et al. Pan-HDAC inhibition by panobinostat mediates chemosensitization to carboplatin in non-small cell lung cancer via attenuation of EGFR signaling. Cancer Lett. 2018, 417, 152-160. [CrossRef]

7. Baek, S.H.; Ko, J.H.; Lee, J.H.; Kim, C.; Lee, H.; Nam, D.; Lee, J.; Lee, S.G.; Yang, W.M.; Um, J.Y.; et al. Ginkgolic Acid Inhibits Invasion and Migration and TGF- $\beta$-Induced EMT of Lung Cancer Cells Through PI3K/Akt/mTOR Inactivation. J. Cell. Physiol. 2017, 232, 346-354. [CrossRef]

8. $\quad$ Ong, P.S.; Wang, L.; Chia, D.M.; Seah, J.Y.; Kong, L.R.; Thuya, W.L.; Chinnathambi, A.; Lau, J.Y.; Wong, A.L.; Yong, W.P.; et al. A novel combinatorial strategy using Seliciclib((R)) and Belinostat((R)) for eradication of non-small cell lung cancer via apoptosis induction and BID activation. Cancer Lett. 2016, 381, 49-57. [CrossRef]

9. Lee, J.H.; Kim, C.; Sethi, G.; Ahn, K.S. Brassinin inhibits STAT3 signaling pathway through modulation of PIAS-3 and SOCS-3 expression and sensitizes human lung cancer xenograft in nude mice to paclitaxel. Oncotarget 2015, 6, 6386-6405. [CrossRef]

10. Yang, P.; Allen, M.S.; Aubry, M.C.; Wampfler, J.A.; Marks, R.S.; Edell, E.S.; Thibodeau, S.; Adjei, A.A.; Jett, J.; Deschamps, C. Clinical features of 5628 primary lung cancer patients: Experience at Mayo Clinic from 1997 to 2003. Chest 2005, 128, 452-462. [CrossRef] 
11. Amin, A.R.; Kucuk, O.; Khuri, F.R.; Shin, D.M. Perspectives for cancer prevention with natural compounds. J. Clin. Oncol. 2009, 27, 2712-2725. [CrossRef] [PubMed]

12. Newman, D.J.; Cragg, G.M.; Snader, K.M. Natural products as sources of new drugs over the period 1981-2002. J. Nat. Prod. 2003, 66, 1022-1037. [CrossRef] [PubMed]

13. Shanmugam, M.K.; Kannaiyan, R.; Sethi, G. Targeting cell signaling and apoptotic pathways by dietary agents: Role in the prevention and treatment of cancer. Nutr. Cancer 2011, 63, 161-173. [CrossRef] [PubMed]

14. Shanmugam, M.K.; Lee, J.H.; Chai, E.Z.; Kanchi, M.M.; Kar, S.; Arfuso, F.; Dharmarajan, A.; Kumar, A.P.; Ramar, P.S.; Looi, C.Y.; et al. Cancer prevention and therapy through the modulation of transcription factors by bioactive natural compounds. Semin. Cancer Biol. 2016, 40-41, 35-47. [CrossRef] [PubMed]

15. Yang, S.F.; Weng, C.J.; Sethi, G.; Hu, D.N. Natural bioactives and phytochemicals serve in cancer treatment and prevention. Evid. Based Complement Altern. Med. 2013, 2013, 698190. [CrossRef] [PubMed]

16. Hsieh, Y.S.; Yang, S.F.; Sethi, G.; Hu, D.N. Natural bioactives in cancer treatment and prevention. Biomed. Res. Int. 2015, 2015, 182835. [CrossRef]

17. Bishayee, A.; Sethi, G. Bioactive natural products in cancer prevention and therapy: Progress and promise. Semin. Cancer Biol. 2016, 40-41, 1-3. [CrossRef]

18. Tewari, D.; Nabavi, S.F.; Nabavi, S.M.; Sureda, A.; Farooqi, A.A.; Atanasov, A.G.; Vacca, R.A.; Sethi, G.; Bishayee, A. Targeting activator protein 1 signaling pathway by bioactive natural agents: Possible therapeutic strategy for cancer prevention and intervention. Pharmacol. Res. 2018, 128, 366-375. [CrossRef]

19. Shanmugam, M.K.; Warrier, S.; Kumar, A.P.; Sethi, G.; Arfuso, F. Potential Role of Natural Compounds as Anti-Angiogenic Agents in Cancer. Curr. Vasc. Pharmacol. 2017, 15, 503-519. [CrossRef]

20. Hasanpourghadi, M.; Looi, C.Y.; Pandurangan, A.K.; Sethi, G.; Wong, W.F.; Mustafa, M.R. Phytometabolites Targeting the Warburg Effect in Cancer Cells: A Mechanistic Review. Curr. Drug. Targets 2017, 18, 1086-1094. [CrossRef]

21. Yarla, N.S.; Bishayee, A.; Sethi, G.; Reddanna, P.; Kalle, A.M.; Dhananjaya, B.L.; Dowluru, K.S.; Chintala, R.; Duddukuri, G.R. Targeting arachidonic acid pathway by natural products for cancer prevention and therapy. Semin. Cancer Biol. 2016, 40-41, 48-81. [CrossRef] [PubMed]

22. Berger, A.; Sexl, V.; Valent, P.; Moriggl, R. Inhibition of STAT5: A therapeutic option in BCR-ABL1-driven leukemia. Oncotarget 2014, 5, 9564-9576. [CrossRef] [PubMed]

23. Weber, A.; Borghouts, C.; Brendel, C.; Moriggl, R.; Delis, N.; Brill, B.; Vafaizadeh, V.; Groner, B. The inhibition of stat 5 by a Peptide aptamer ligand specific for the DNA binding domain prevents target gene transactivation and the growth of breast and prostate tumor cells. Pharmaceuticals (Basel) 2013, 6, 960-987. [CrossRef] [PubMed]

24. Weber, A.; Borghouts, C.; Brendel, C.; Moriggl, R.; Delis, N.; Brill, B.; Vafaizadeh, V.; Groner, B. Stat5 Exerts Distinct, Vital Functions in the Cytoplasm and Nucleus of Bcr-Abl+ K562 and Jak2(V617F)+ HEL Leukemia Cells. Cancers (Basel) 2015, 7, 503-537. [CrossRef]

25. Bunting, K.D. STAT5 signaling in normal and pathologic hematopoiesis. Front Biosci. 2007, 12, $2807-2820$. [CrossRef] [PubMed]

26. Bourgeais, J.; Ishac, N.; Medrzycki, M.; Brachet-Botineau, M.; Desbourdes, L.; Gouilleux-Gruart, V.; Pecnard, E.; Rouleux-Bonnin, F.; Gyan, E.; Domenech, J.; et al. Oncogenic STAT5 signaling promotes oxidative stress in chronic myeloid leukemia cells by repressing antioxidant defenses. Oncotarget 2017, 8 , 41876-41889. [CrossRef]

27. Kucuk, C.; Jiang, B.; Hu, X.; Zhang, W.; Chan, J.K.; Xiao, W.; Lack, N.; Alkan, C.; Williams, J.C.; Avery, K.N.; et al. Activating mutations of STAT5B and STAT3 in lymphomas derived from gammadelta-T or NK cells. Nat. Commun. 2015, 6, 6025. [CrossRef]

28. Bandapalli, O.R.; Schuessele, S.; Kunz, J.B.; Rausch, T.; Stutz, A.M.; Tal, N.; Geron, I.; Gershman, N.; Izraeli, S.; Eilers, J.; et al. The activating STAT5B N642H mutation is a common abnormality in pediatric T-cell acute lymphoblastic leukemia and confers a higher risk of relapse. Haematologica 2014, 99, e188-e192. [CrossRef]

29. Vafaizadeh, V.; Klemmt, P.; Brendel, C.; Weber, K.; Doebele, C.; Britt, K.; Grez, M.; Fehse, B.; Desrivieres, S.; Groner, B. Mammary epithelial reconstitution with gene-modified stem cells assigns roles to Stat5 in luminal alveolar cell fate decisions, differentiation, involution, and mammary tumor formation. Stem. Cells 2010, 28, 928-938. [CrossRef]

30. Walker, S.R.; Xiang, M.; Frank, D.A. Distinct roles of STAT3 and STAT5 in the pathogenesis and targeted therapy of breast cancer. Mol. Cell Endocrinol. 2014, 382, 616-621. [CrossRef] 
31. Rani, A.; Murphy, J.J. STAT5 in Cancer and Immunity. J. Interferon Cytokine Res. 2016, 36, 226-237. [CrossRef] [PubMed]

32. Gouilleux, F.; Wakao, H.; Mundt, M.; Groner, B. Prolactin induces phosphorylation of Tyr694 of Stat5 (MGF), a prerequisite for DNA binding and induction of transcription. EMBO J 1994, 13, 4361-4369. [CrossRef] [PubMed]

33. Thomas, S.J.; Snowden, J.A.; Zeidler, M.P.; Danson, S.J. The role of JAK/STAT signalling in the pathogenesis, prognosis and treatment of solid tumours. Br. J. Cancer 2015, 113, 365-371. [CrossRef] [PubMed]

34. Britschgi, A.; Andraos, R.; Brinkhaus, H.; Klebba, I.; Romanet, V.; Muller, U.; Murakami, M.; Radimerski, T.; Bentires-Alj, M. JAK2/STAT5 inhibition circumvents resistance to PI3K/mTOR blockade: A rationale for cotargeting these pathways in metastatic breast cancer. Cancer Cell 2012, 22, 796-811. [CrossRef] [PubMed]

35. Schmidt, J.W.; Wehde, B.L.; Sakamoto, K.; Triplett, A.A.; Anderson, S.M.; Tsichlis, P.N.; Leone, G.; Wagner, K.U. Stat5 regulates the phosphatidylinositol 3-kinase/Akt1 pathway during mammary gland development and tumorigenesis. Mol. Cell Biol. 2014, 34, 1363-1377. [CrossRef]

36. Bibi, S.; Arslanhan, M.D.; Langenfeld, F.; Jeanningros, S.; Cerny-Reiterer, S.; Hadzijusufovic, E.; Tchertanov, L.; Moriggl, R.; Valent, P.; Arock, M. Co-operating STAT5 and AKT signaling pathways in chronic myeloid leukemia and mastocytosis: Possible new targets of therapy. Haematologica 2014, 99, 417-429. [CrossRef]

37. Cao, S.; Yan, Y.; Zhang, X.; Zhang, K.; Liu, C.; Zhao, G.; Han, J.; Dong, Q.; Shen, B.; Wu, A.; et al. EGF stimulates cyclooxygenase-2 expression through the STAT5 signaling pathway in human lung adenocarcinoma A549 cells. Int. J. Oncol. 2011, 39, 383-391.

38. Sun, W.; Ma, Y.; Chen, P.; Wang, D. MicroRNA-10a silencing reverses cisplatin resistance in the A549/cisplatin human lung cancer cell line via the transforming growth factor-beta/Smad2/STAT3/STAT5 pathway. Mol. Med. Rep. 2015, 11, 3854-3859. [CrossRef]

39. Kim, C.; Lee, S.G.; Yang, W.M.; Arfuso, F.; Um, J.Y.; Kumar, A.P.; Bian, J.; Sethi, G.; Ahn, K.S. Formononetin-induced oxidative stress abrogates the activation of STAT3/5 signaling axis and suppresses the tumor growth in multiple myeloma preclinical model. Cancer Lett. 2018, 431, 123-141. [CrossRef]

40. Desrivieres, S.; Kunz, C.; Barash, I.; Vafaizadeh, V.; Borghouts, C.; Groner, B. The biological functions of the versatile transcription factors STAT3 and STAT5 and new strategies for their targeted inhibition. J Mammary Gland Biol. Neoplasia 2006, 11, 75-87. [CrossRef]

41. Kim, C.; Lee, J.H.; Kim, S.H.; Sethi, G.; Ahn, K.S. Artesunate suppresses tumor growth and induces apoptosis through the modulation of multiple oncogenic cascades in a chronic myeloid leukemia xenograft mouse model. Oncotarget 2015, 6, 4020-4035. [CrossRef] [PubMed]

42. Walker, S.R.; Xiang, M.; Frank, D.A. STAT3 Activity and Function in Cancer: Modulation by STAT5 and miR-146b. Cancers (Basel) 2014, 6, 958-968. [CrossRef] [PubMed]

43. Furqan, M.; Akinleye, A.; Mukhi, N.; Mittal, V.; Chen, Y.; Liu, D. STAT inhibitors for cancer therapy. J. Hematol. Oncol. 2013, 6, 90. [CrossRef] [PubMed]

44. Freund, P.; Kerenyi, M.A.; Hager, M.; Wagner, T.; Wingelhofer, B.; Pham, H.T.T.; Elabd, M.; Han, X.; Valent, P.; Gouilleux, F.; et al. O-GlcNAcylation of STAT5 controls tyrosine phosphorylation and oncogenic transcription in STAT5-dependent malignancies. Leukemia 2017, 31, 2132-2142. [CrossRef] [PubMed]

45. Shin, H.Y.; Reich, N.C. Dynamic trafficking of STAT5 depends on an unconventional nuclear localization signal. J. Cell. Sci. 2013, 126, 3333-3343. [CrossRef] [PubMed]

46. Wang, W.; You, R.L.; Qin, W.J.; Hai, L.N.; Fang, M.J.; Huang, G.H.; Kang, R.X.; Li, M.H.; Qiao, Y.F.; Li, J.W.; et al. Anti-tumor activities of active ingredients in Compound Kushen Injection. Acta Pharmacol. Sin. 2015, 36, 676-679. [CrossRef] [PubMed]

47. Sun, M.; Cao, H.; Sun, L.; Dong, S.; Bian, Y.; Han, J.; Zhang, L.; Ren, S.; Hu, Y.; Liu, C.; et al. Antitumor activities of kushen: Literature review. Evid. Based Complement Altern. Med. 2012, 2012, 373219. [CrossRef]

48. Yu, L.; Zhou, Y.; Yang, Y.; Lu, F.; Fan, Y. Efficacy and Safety of Compound Kushen Injection on Patients with Advanced Colon Cancer: A Meta-Analysis of Randomized Controlled Trials. Evid. Based Complement Altern. Med. 2017, 2017, 7102514. [CrossRef]

49. Yin, S.Y.; Wei, W.C.; Jian, F.Y.; Yang, N.S. Therapeutic applications of herbal medicines for cancer patients. Evid. Based Complement Altern. Med. 2013, 2013, 302426. [CrossRef]

50. Liu, Y.; Xu, Y.; Ji, W.; Li, X.; Sun, B.; Gao, Q.; Su, C. Anti-tumor activities of matrine and oxymatrine: Literature review. Tumour Biol. 2014, 35, 5111-5119. [CrossRef] 
51. Zhang, Y.; Piao, B.; Zhang, Y.; Hua, B.; Hou, W.; Xu, W.; Qi, X.; Zhu, X.; Pei, Y.; Lin, H. Oxymatrine diminishes the side population and inhibits the expression of beta-catenin in MCF-7 breast cancer cells. Med. Oncol. 2011, 28 (Suppl. S1), S99-S107. [CrossRef]

52. Ling, Q.; Xu, X.; Wei, X.; Wang, W.; Zhou, B.; Wang, B.; Zheng, S. Oxymatrine induces human pancreatic cancer PANC-1 cells apoptosis via regulating expression of Bcl-2 and IAP families, and releasing of cytochrome c. J. Exp. Clin. Cancer Res. 2011, 30, 66. [CrossRef] [PubMed]

53. Song, M.Q.; Zhu, J.S.; Chen, J.L.; Wang, L.; Da, W.; Zhu, L.; Zhang, W.P. Synergistic effect of oxymatrine and angiogenesis inhibitor NM-3 on modulating apoptosis in human gastric cancer cells. World J. Gastroenterol. 2007, 13, 1788-1793. [CrossRef] [PubMed]

54. Song, G.; Luo, Q.; Qin, J.; Wang, L.; Shi, Y.; Sun, C. Effects of oxymatrine on proliferation and apoptosis in human hepatoma cells. Colloids Surf. B Biointerfaces 2006, 48, 1-5. [CrossRef] [PubMed]

55. Liu, Y.; Bi, T.; Dai, W.; Wang, G.; Qian, L.; Gao, Q.; Shen, G. Oxymatrine synergistically enhances the inhibitory effect of 5-fluorouracil on hepatocellular carcinoma in vitro and in vivo. Tumour Biol. 2016, 37, 7589-7597. [CrossRef] [PubMed]

56. Wu, C.; Huang, W.; Guo, Y.; Xia, P.; Sun, X.; Pan, X.; Hu, W. Oxymatrine inhibits the proliferation of prostate cancer cells in vitro and in vivo. Mol. Med. Rep. 2015, 11, 4129-4134. [CrossRef] [PubMed]

57. Li, J.; Jiang, K.; Zhao, F. Oxymatrine suppresses proliferation and facilitates apoptosis of human ovarian cancer cells through upregulating microRNA29b and downregulating matrix metalloproteinase2 expression. Mol. Med. Rep. 2015, 12, 5369-5374. [CrossRef]

58. Guo, B.; Zhang, T.; Su, J.; Wang, K.; Li, X. Oxymatrine targets EGFR(p-Tyr845) and inhibits EGFR-related signaling pathways to suppress the proliferation and invasion of gastric cancer cells. Cancer Chemother. Pharmacol. 2015, 75, 353-363. [CrossRef]

59. Wang, X.; Liu, C.; Wang, J.; Fan, Y.; Wang, Z.; Wang, Y. Oxymatrine inhibits the migration of human colorectal carcinoma RKO cells via inhibition of PAI-1 and the TGF-beta1/Smad signaling pathway. Oncol. Rep. 2017, 37, 747-753. [CrossRef]

60. Liu, Y.; Bi, T.; Wang, Z.; Wu, G.; Qian, L.; Gao, Q.; Shen, G. Oxymatrine synergistically enhances antitumor activity of oxaliplatin in colon carcinoma through PI3K/AKT/mTOR pathway. Apoptosis 2016, 21, 1398-1407. [CrossRef]

61. Xiong, Y.; Wang, J.; Zhu, H.; Liu, L.; Jiang, Y. Chronic oxymatrine treatment induces resistance and epithelialmesenchymal transition through targeting the long non-coding RNA MALAT1 in colorectal cancer cells. Oncol. Rep. 2018, 39, 967-976. [PubMed]

62. Lin, B.; Li, D.; Zhang, L. Oxymatrine mediates Bax and Bcl-2 expression in human breast cancer MCF-7 cells. Pharmazie 2016, 71, 154-157. [PubMed]

63. Wu, J.; Cai, Y.; Li, M.; Zhang, Y.; Li, H.; Tan, Z. Oxymatrine Promotes S-Phase Arrest and Inhibits Cell Proliferation of Human Breast Cancer Cells in Vitro through Mitochondria-Mediated Apoptosis. Biol. Pharm. Bull. 2017, 40, 1232-1239. [CrossRef] [PubMed]

64. Li, S.; Zhang, Y.; Liu, Q.; Zhao, Q.; Xu, L.; Huang, S.; Huang, S.; Wei, X. Oxymatrine inhibits proliferation of human bladder cancer T24 cells by inducing apoptosis and cell cycle arrest. Oncol. Lett. 2017, 13, 4453-4458. [CrossRef] [PubMed]

65. Jin, Y.; Hu, J.; Wang, Q.; Li, Z.; Chen, Y. Effects of Oxymatrine on the apoptosis of human esophageal carcinoma Eca109 cell line and its mechanism. J. Huazhong Univ. Sci. Technol. Med. Sci. 2008, 28, 314-316. [CrossRef] [PubMed]

66. Zhang, Y.; Sun, S.; Chen, J.; Ren, P.; Hu, Y.; Cao, Z.; Sun, H.; Ding, Y. Oxymatrine induces mitochondria dependent apoptosis in human osteosarcoma MNNG/HOS cells through inhibition of PI3K/Akt pathway. Tumour Biol. 2014, 35, 1619-1625. [CrossRef] [PubMed]

67. Wei, J.; Zhu, Y.; Xu, G.; Yang, F.; Guan, Z.; Wang, M.; Fang, Y. Oxymatrine extracted from Sophora flavescens inhibited cell growth and induced apoptosis in human osteosarcoma MG-63 cells in vitro. Cell Biochem. Biophys. 2014, 70, 1439-1444. [CrossRef]

68. Li, M.; Su, B.S.; Chang, L.H.; Gao, Q.; Chen, K.L.; An, P.; Huang, C.; Yang, J.; Li, Z.F. Oxymatrine induces apoptosis in human cervical cancer cells through guanine nucleotide depletion. Anticancer Drugs 2014, 25, 161-173. [CrossRef] 
69. Pei, Z.; Zeng, J.; Gao, Y.; Li, F.; Li, W.; Zhou, H.; Yang, Y.; Wu, R.; Chen, Y.; Liu, J. Oxymatrine inhibits the proliferation of CaSki cells via downregulating HPV16E7 expression. Oncol. Rep. 2016, 36, $291-298$. [CrossRef]

70. Wu, X.S.; Yang, T.; Gu, J.; Li, M.L.; Wu, W.G.; Weng, H.; Ding, Q.; Mu, J.S.; Bao, R.F.; Shu, Y.J.; et al. Effects of oxymatrine on the apoptosis and proliferation of gallbladder cancer cells. Anticancer Drugs 2014, 25, 1007-1015. [CrossRef]

71. Ying, X.J.; Jin, B.; Chen, X.W.; Xie, J.; Xu, H.M.; Dong, P. Oxymatrine downregulates HPV16E7 expression and inhibits cell proliferation in laryngeal squamous cell carcinoma Hep-2 cells in vitro. Biomed. Res. Int. 2015, 2015, 150390. [CrossRef] [PubMed]

72. Fei, Z.W.; Qiu, M.K.; Qi, X.Q.; Dai, Y.X.; Wang, S.Q.; Quan, Z.W.; Liu, Y.B.; Ou, J.M. Oxymatrine suppresses proliferation and induces apoptosis of hemangioma cells through inhibition of HIF-1a signaling. Int. J. Immunopathol. Pharmacol. 2015, 28, 201-208. [CrossRef] [PubMed]

73. Wang, B.; Han, Q.; Zhu, Y. Oxymatrine inhibited cell proliferation by inducing apoptosis in human lung cancer A549 cells. Biomed. Mater Eng. 2015, 26 (Suppl. S1), S165-S172. [CrossRef] [PubMed]

74. Wang, Z.; Xu, W.; Lin, Z.; Li, C.; Wang, Y.; Yang, L.; Liu, G. Reduced apurinic/apyrimidinic endonuclease activity enhances the antitumor activity of oxymatrine in lung cancer cells. Int. J. Oncol. 2016, 49, 2331-2340. [CrossRef]

75. Zhou, G.Z.; Shi, Y.Y.; Cui, L.S.; Li, A.F.; Wang, Q.Q.; Liu, M. Oxymatrine induces A549 human nonsmall lung cancer cell apoptosis via extrinsic and intrinsic pathways. Mol. Med. Rep. 2018, 17, 1071-1076. [PubMed]

76. Li, W.; Yu, X.; Tan, S.; Liu, W.; Zhou, L.; Liu, H. Oxymatrine inhibits non-small cell lung cancer via suppression of EGFR signaling pathway. Cancer Med. 2018, 7, 208-218. [CrossRef]

77. Cai, Y.; Xu, P.; Yang, L.; Xu, K.; Zhu, J.; Wu, X.; Jiang, C.; Yuan, Q.; Wang, B.; Li, Y.; et al. HMGB1-mediated autophagy decreases sensitivity to oxymatrine in SW982 human synovial sarcoma cells. Sci. Rep. 2016, 6, 37845. [CrossRef]

78. Liu, F.; Wang, B.; Wang, J.; Ling, X.; Li, Q.; Meng, W.; Ma, J. Oxymatrine Inhibits Proliferation and Migration While Inducing Apoptosis in Human Glioblastoma Cells. Biomed. Res. Int. 2016, 2016, 1784161. [CrossRef]

79. Dai, Z.; Wang, L.; Wang, X.; Zhao, B.; Zhao, W.; Bhardwaj, S.S.; Ye, J.; Yin, Z.; Zhang, J.; Zhao, S. Oxymatrine induces cell cycle arrest and apoptosis and suppresses the invasion of human glioblastoma cells through the EGFR/PI3K/Akt/mTOR signaling pathway and STAT3. Oncol. Rep. 2018, 40, 867-876. [CrossRef]

80. Ni, Z.; Yi, J. Oxymatrine induces nasopharyngeal cancer cell death through inhibition of PI3K/AKT and NFkappaB pathways. Mol. Med. Rep. 2017, 16, 9701-9706. [CrossRef]

81. He, M.; Jiang, L.; Li, B.; Wang, G.; Wang, J.; Fu, Y. Oxymatrine suppresses the growth and invasion of MG63 cells by up-regulating PTEN and promoting its nuclear translocation. Oncotarget 2017, 8, 65100-65110. [CrossRef]

82. Chen, H.; Zhang, J.; Luo, J.; Lai, F.; Wang, Z.; Tong, H.; Lu, D.; Bu, H.; Zhang, R.; Lin, S. Antiangiogenic effects of oxymatrine on pancreatic cancer by inhibition of the NF-kappaB-mediated VEGF signaling pathway. Oncol. Rep. 2013, 30, 589-595. [CrossRef]

83. Shao, H.; Yang, B.; Hu, R.; Wang, Y. Matrine effectively inhibits the proliferation of breast cancer cells through a mechanism related to the NF-kappaB signaling pathway. Oncol. Lett. 2013, 6, 517-520. [CrossRef]

84. Li, L.Q.; Li, X.L.; Wang, L.; Du, W.J.; Guo, R.; Liang, H.H.; Liu, X.; Liang, D.S.; Lu, Y.J.; Shan, H.L.; et al. Matrine inhibits breast cancer growth via miR-21/PTEN/Akt pathway in MCF-7 cells. Cell Physiol. Biochem. 2012, 30, 631-641. [CrossRef]

85. Dai, Z.J.; Gao, J.; Ji, Z.Z.; Wang, X.J.; Ren, H.T.; Liu, X.X.; Wu, W.Y.; Kang, H.F.; Guan, H.T. Matrine induces apoptosis in gastric carcinoma cells via alteration of Fas/FasL and activation of caspase-3. J. Ethnopharmacol. 2009, 123, 91-96. [CrossRef]

86. Luo, C.; Zhu, Y.; Jiang, T.; Lu, X.; Zhang, W.; Jing, Q.; Li, J.; Pang, L.; Chen, K.; Qiu, F.; et al. Matrine induced gastric cancer MKN45 cells apoptosis via increasing pro-apoptotic molecules of Bcl-2 family. Toxicology 2007, 229, 245-252. [CrossRef]

87. Li, H.; Xie, S.; Liu, X.; Wu, H.; Lin, X.; Gu, J.; Wang, H.; Duan, Y. Matrine alters microRNA expression profiles in SGC-7901 human gastric cancer cells. Oncol. Rep. 2014, 32, 2118-2126. [CrossRef]

88. Pastuszak-Lewandoska, D.; Domanska, D.; Czarnecka, K.H.; Kordiak, J.; Migdalska-Sek, M.; Nawrot, E.; Kiszalkiewicz, J.; Antczak, A.; Gorski, P.; Brzezianska, E. Expression of STAT5, COX-2 and PIAS3 in correlation with NSCLC histhopathological features. PLoS ONE 2014, 9, e104265. [CrossRef] 
89. Pastuszak-Lewandoska, D.; Domanska-Senderowska, D.; Kordiak, J.; Antczak, A.; Czarnecka, K.H.; Migdalska-Sek, M.; Nawrot, E.; Kiszalkiewicz, J.M.; Brzezianska-Lasota, E. Immunoexpression analysis of selected JAK/STAT pathway molecules in patients with non- small-cell lung cancer. Pol. Arch. Int. Med. 2017, 127, 758-764. [CrossRef]

90. Sanchez-Ceja, S.G.; Reyes-Maldonado, E.; Vazquez-Manriquez, M.E.; Lopez-Luna, J.J.; Belmont, A.; Gutierrez-Castellanos, S. Differential expression of STAT5 and Bcl-xL, and high expression of Neu and STAT3 in non-small-cell lung carcinoma. Lung Cancer 2006, 54, 163-168. [CrossRef]

91. Groner, B.; von Manstein, V. Jak Stat signaling and cancer: Opportunities, benefits and side effects of targeted inhibition. Mol. Cell Endocrinol. 2017, 451,1-14. [CrossRef] [PubMed]

92. Mirtti, T.; Leiby, B.E.; Abdulghani, J.; Aaltonen, E.; Pavela, M.; Mamtani, A.; Alanen, K.; Egevad, L.; Granfors, T.; Josefsson, A.; et al. Nuclear Stat5a/b predicts early recurrence and prostate cancer-specific death in patients treated by radical prostatectomy. Hum. Pathol. 2013, 44, 310-319. [CrossRef]

93. Cumaraswamy, A.A.; Lewis, A.M.; Geletu, M.; Todic, A.; Diaz, D.B.; Cheng, X.R.; Brown, C.E.; Laister, R.C.; Muench, D.; Kerman, K.; et al. Nanomolar-Potency Small Molecule Inhibitor of STAT5 Protein. ACS Med. Chem. Lett. 2014, 5, 1202-1206. [CrossRef] [PubMed]

94. de Araujo, E.D.; Manaswiyoungkul, P.; Erdogan, F.; Qadree, A.K.; Sina, D.; Tin, G.; Toutah, K.; Yuen, K.; Gunning, P.T. A functional in vitro assay for screening inhibitors of STAT5B phosphorylation. J. Pharm. Biomed. Anal. 2019, 162, 60-65. [CrossRef]

95. Mi, T.; Wang, Z.; Bunting, K.D. The Cooperative Relationship between STAT5 and Reactive Oxygen Species in Leukemia: Mechanism and Therapeutic Potential. Cancers (Basel) 2018, 10, 359. [CrossRef] [PubMed]

96. Wingelhofer, B.; Maurer, B.; Heyes, E.C.; Cumaraswamy, A.A.; Berger-Becvar, A.; de Araujo, E.D.; Orlova, A.; Freund, P.; Ruge, F.; Park, J.; et al. Pharmacologic inhibition of STAT5 in acute myeloid leukemia. Leukemia 2018, 32, 1135-1146. [CrossRef]

97. Wingelhofer, B.; Neubauer, H.A.; Valent, P.; Han, X.; Constantinescu, S.N.; Gunning, P.T.; Muller, M.; Moriggl, R. Implications of STAT3 and STAT5 signaling on gene regulation and chromatin remodeling in hematopoietic cancer. Leukemia 2018, 32, 1713-1726. [CrossRef]

98. Yu, H.; Lee, H.; Herrmann, A.; Buettner, R.; Jove, R. Revisiting STAT3 signalling in cancer: New and unexpected biological functions. Nat. Rev. Cancer 2014, 14, 736-746. [CrossRef]

99. Darnell, J.E., Jr. Transcription factors as targets for cancer therapy. Nat. Rev. Cancer 2002, 2, 740-749. [CrossRef]

100. Wong, A.L.A.; Hirpara, J.L.; Pervaiz, S.; Eu, J.Q.; Sethi, G.; Goh, B.C. Do STAT3 inhibitors have potential in the future for cancer therapy? Expert Opin. Investig. Drugs 2017, 26, 883-887. [CrossRef]

101. Liu, L.; Ahn, K.S.; Shanmugam, M.K.; Wang, H.; Shen, H.; Arfuso, F.; Chinnathambi, A.; Alharbi, S.A.; Chang, Y.; Sethi, G.; et al. Oleuropein induces apoptosis via abrogating NF-kappaB activation cascade in estrogen receptor-negative breast cancer cells. J. Cell Biochem. 2018.

102. Jung, Y.Y.; Lee, J.H.; Nam, D.; Narula, A.S.; Namjoshi, O.A.; Blough, B.E.; Um, J.Y.; Sethi, G.; Ahn, K.S. Anti-myeloma Effects of Icariin Are Mediated Through the Attenuation of JAK/STAT3-Dependent Signaling Cascade. Front Pharmacol. 2018, 9, 531. [CrossRef]

103. Lee, J.H.; Kim, C.; Baek, S.H.; Ko, J.H.; Lee, S.G.; Yang, W.M.; Um, J.Y.; Sethi, G.; Ahn, K.S. Capsazepine inhibits JAK/STAT3 signaling, tumor growth, and cell survival in prostate cancer. Oncotarget 2017, 8, 17700-17711. [CrossRef] [PubMed]

104. Lee, J.H.; Kim, C.; Kim, S.H.; Sethi, G.; Ahn, K.S. Farnesol inhibits tumor growth and enhances the anticancer effects of bortezomib in multiple myeloma xenograft mouse model through the modulation of STAT3 signaling pathway. Cancer Lett. 2015, 360, 280-293. [CrossRef] [PubMed]

(C) 2019 by the authors. Licensee MDPI, Basel, Switzerland. This article is an open access article distributed under the terms and conditions of the Creative Commons Attribution (CC BY) license (http:/ / creativecommons.org/licenses/by/4.0/). 